\title{
Carbonate platform growth and cyclicity at a terminal Proterozoic passive margin, Infra Krol Formation and Krol Group, Lesser Himalaya, India
}

\author{
GANQING JIANG*, NICHOLAS CHRISTIE-BLICK†, ALAN J. KAUFMAN \\ DHIRAJ M. BANERJEE $\S$ and VIBHUTI RAI \\ ${ }^{*}$ Department of Earth Sciences, University of California, Riverside, CA 92521, USA \\ (E-mail: ganqing@mail.ucr.edu) \\ $\dagger$ Department of Earth and Environmental Sciences and Lamont-Doherty Earth Observatory, Columbia \\ University, Palisades, NY 10964-8000, USA \\ $\ddagger$ Department of Geology, University of Maryland, College Park, MD 20742-4211, USA \\ $\S$ Department of Geology, University of Delhi, Delhi 110007, India \\ -Department of Geology, Lucknow University, Lucknow 226007, India
}

\begin{abstract}
The Infra Krol Formation and overlying Krol Group constitute a thick $(<2 \mathrm{~km})$, carbonate-rich succession of terminal Proterozoic age that crops out in a series of doubly plunging synclines in the Lesser Himalaya of northern India. The rocks include 18 carbonate and siliciclastic facies, which are grouped into eight facies associations: (1) deep subtidal; (2) shallow subtidal; (3) sand shoal; (4) peritidal carbonate complex; (5) lagoonal; (6) peritidal siliciclastic-carbonate; (7) incised valley fill; and (8) karstic fill. The stromatolite-rich, peritidal complex appears to have occupied a location seaward of a broad lagoon, an arrangement reminiscent of many Phanerozoic and Proterozoic platforms. Growth of this complex was accretionary to progradational, in response to changes in siliciclastic influx from the south-eastern side of the lagoon. Metre-scale cycles tend to be laterally discontinuous, and are interpreted as mainly autogenic. Variations in the number of both sets of cycles and component metre-scale cycles across the platform may result from differential subsidence of the interpreted passive margin. Apparently non-cyclic intervals with shallow-water features may indicate facies migration that was limited compared with the dimensions of facies belts. Correlation of these facies associations in a sequence stratigraphic framework suggests that the Infra Krol Formation and Krol Group represent a north- to north-westfacing platform with a morphology that evolved from a siliciclastic ramp, to carbonate ramp, to peritidal rimmed shelf and, finally, to open shelf. This interpretation differs significantly from the published scheme of a basin centred on the Lesser Himalaya, with virtually the entire Infra Krol-Krol succession representing sedimentation in a persistent tidal-flat environment. This study provides a detailed Neoproterozoic depositional history of northern India from rift basin to passive margin, and predicts that genetically related Neoproterozoic deposits, if they are present in the High Himalaya, are composed mainly of slope/basinal facies characterized by fine-grained siliciclastic and detrital carbonate rocks, lithologically different from those of the Lesser Himalaya.
\end{abstract}

Keywords Cycles, facies, Infra Krol Formation, Krol Group, Lesser Himalaya, platform evolution, terminal Proterozoic. 


\section{INTRODUCTION}

Recent studies of Precambrian carbonate rocks have demonstrated that late Archaean to Neoproterozoic carbonate platforms are characterized by architecture, primary mineralogy and facies distributions that are similar to those present in Palaeozoic to Recent platforms (e.g. Grotzinger, 1986a, 1989a,b; Beukes, 1987; Hoffman, 1989; Sami \& James, 1994; Grotzinger \& James, 2000). In the absence of skeletal metazoans and green algae in all but the latest Neoproterozoic, stromatolites and microbiota may have played an essential role in the construction of wave-resistant buildups at platform margins and in the production of carbonate mud, comparable to the roles of higher organisms in Phanerozoic examples (e.g. Sami \& James, 1994; Grotzinger \& James, 2000). It has also been shown that interpreted upward-shoaling metre-scale units or 'cycles' in some Proterozoic carbonate platforms trace laterally with consistent stacking patterns for tens to hundreds of kilometres (e.g. Grotzinger, 1986b; Dehler et al., 2001), again similar to a number of purported Phanerozoic examples (e.g. Goldhammer et al., 1990, 1993; Osleger \& Read, 1991; Montañez \& Osleger, 1993; Elrick, 1995; Bosence et al., 2000).

The Neoproterozoic is of special interest for the study of carbonate platform evolution and depositional cycles. In comparison with Palaeoproterozoic and Mesoproterozoic counterparts, preserved Neoproterozoic carbonate rocks appear to have accumulated mainly on ramps rather than on rimmed shelves (Grotzinger, 1989b; Grotzinger \& James, 2000). The reason for the predominance of Neoproterozoic ramps is uncertain, but perhaps related to a general association in most basins with siliciclastic sedimentation. Few carbonate-dominated systems of this age have been adequately documented. A second feature of the Neoproterozoic is that it is an interval of unusually widespread glaciation, although with some ongoing debate about the number and timing of ice ages, and the manner in which deposits correlate from one place to another (Kaufman et al., 1997; Hoffman et al., 1998; Kennedy et al., 1998; Crowell, 1999; Sohl et al., 1999). Metre-scale upward-shoaling 'cycles' are an anticipated consequence of carbonate sedimentation during times of glacio-eustatic change.

It is in this context that we studied the sedimentology of the Infra Krol Formation and Krol Group of the Lesser Himalaya, India, one of the most carbonate-rich successions of terminal Proterozoic age. The primary goals of this paper are: (1) to document details of regional facies patterns and their implications for platform architecture; (2) to present examples of metrescale 'cycles', their lateral variability and their stacking patterns; and (3) to interpret the evolution of the platform through time. Here, we use the term 'cycle' in a purely descriptive sense for repeated intervals of palaeowater depth change without implying periodicity.

\section{GEOLOGICAL SETTING}

The Infra Krol Formation and Krol Group together constitute a succession of mostly fine-grained siliciclastic and carbonate rocks that crop out over a distance of $280 \mathrm{~km}$ in the Lesser Himalaya of northern India (Fig. 1; Bhargava, 1979; Shanker et al., 1989, 1993; Shanker \& Mathur, 1992). These rocks are as much as $2 \mathrm{~km}$ thick, and are of terminal Proterozoic age $(\approx 590-543 \mathrm{Ma}$; Jiang et al., 2002). They overlie the glacial-marine Blaini Formation and underlie the predominantly siliciclastic Tal Group (Fig. 2).

Two prevailing ideas have been published on the Infra Krol-Krol succession in the Lesser Himalaya. One is that all the sediment accumulated in a basin centred on Mussoorie syncline, where both stratigraphic thickness and palaeowater depths have been interpreted to achieve maximum values (Fig. 3; Shanker et al., 1989, 1993; Shanker \& Mathur, 1992). That interpretation is based on lithic correlation, which is assumed to approximate time correlation (Fig. 3). However, suggested correlation schemes vary in detail from one author to another, and the absence of anticipated basinal or slope facies at Mussoorie syncline casts doubt on their validity. A second widely accepted idea is that the Krol represents the sedimentary record of a tidal flat sea that extended southward across the Indian Peninsula with little variation in palaeowater depth either spatially or as a function of time (Singh, 1980a,b; Singh \& Rai, 1980; Singh et al., 1980; Bhargava \& Singh, 1981; Tangri \& Singh, 1982). This interpretation finds support in the presence of locally abundant shallow-water indicators in the rocks (microbial laminae, fenestral structure, gypsum casts and desiccation cracks), but it fails to account for the full range of facies present or for their systematic arrangements in three dimensions.

Our revised interpretation, based on sequence stratigraphic analysis, is that the Infra Krol-Krol succession was deposited at the inner part of a north- to north-west-facing passive continental 


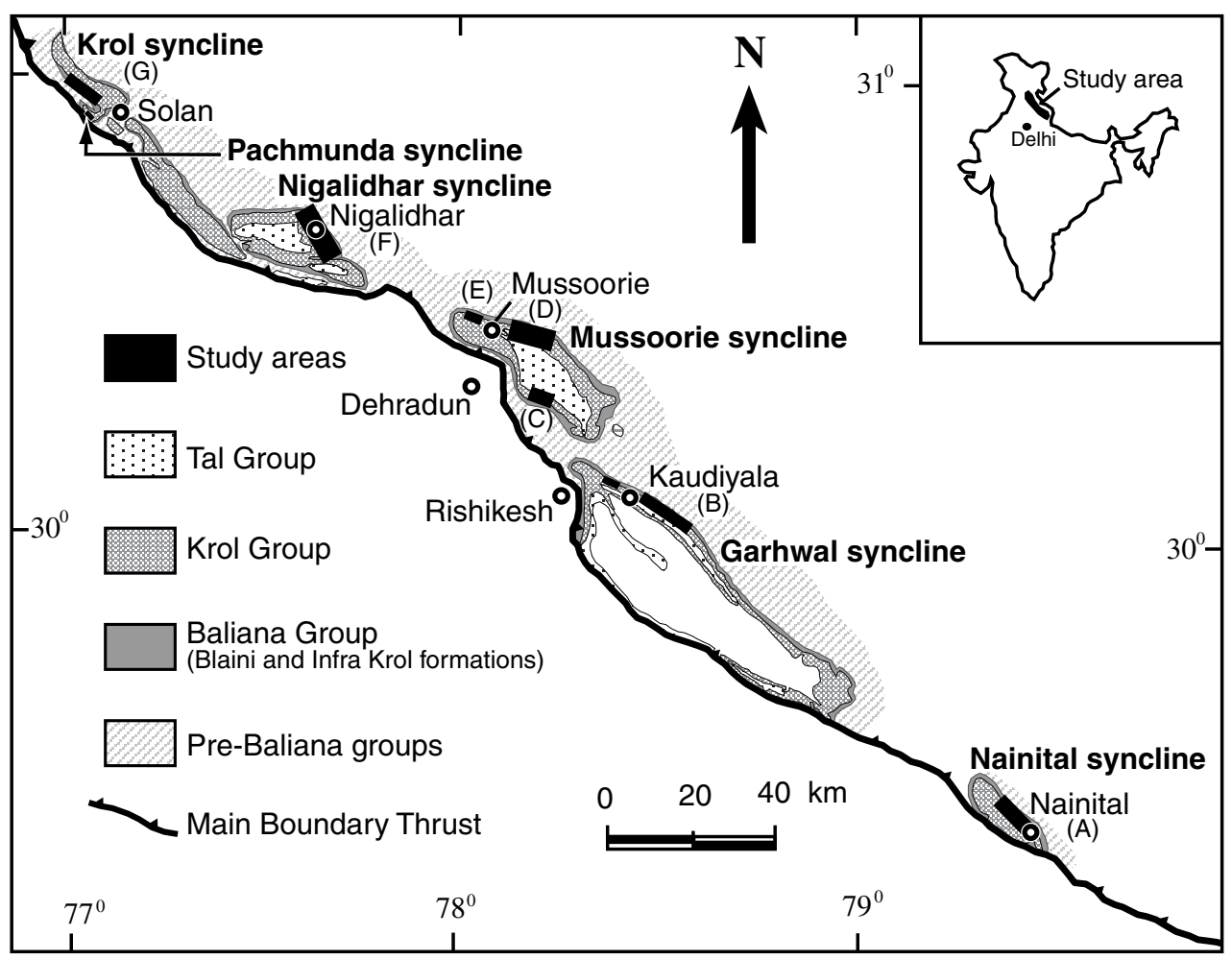

Fig. 1. Map showing exposures of the Baliana, Krol and Tal groups in Lesser Himalaya fold and thrust belt and study areas (after Singh \& Rai, 1983). Letters (A) to (G) are locations of representative sections shown in Fig. 4.

margin (Fig. 4; Brookfield, 1993; Jiang et al., 2002; see below). Eight regional stratigraphic discontinuities have been traced throughout the Lesser Himalaya, including three that are interpreted as sequence boundaries (surfaces 2, 4 and 5 in Fig. 4). Regional facies distribution anchored in this physical stratigraphic framework indicates that platform architecture evolved through time, from siliciclastic and carbonate ramps to rimmed shelf and to open shelf (Figs 5 and 6). Although no slope or basinal facies crop out in the Lesser Himalaya, our interpretation is supported by several lines of evidence. First, in contrast to published interpretations, the Infra Krol-Krol succession thickens gradually but consistently towards the north-west (Fig. 4). Previously interpreted thinning in the vicinity of Solan and at Nigalidhar syncline (Fig. 3) is due to poor exposure of the upper part of the Krol Group in those areas, and apparent thickening at Mussoorie and Nainital synclines results from tectonic repetition. Our thickness estimates are based on numerous, well-correlated sections in the best outcrops. Secondly, siliciclastic rocks increase in abundance towards the south-east (Fig. 4). For example, near Solan and at Nigalidhar syncline, strata above surface 3 are composed mainly of carbonate, with only minor shale and siltstone found preferentially above flooding surfaces. Within the same stratigraphic interval at Mussoorie syncline, interbedded siltstone and cherty/ silty dolomite are comparatively abundant. Similarly, at Garhwal syncline, strata above surface 4 are composed primarily of interbedded siltstone and cherty/silty dolomite (except for the uppermost Krol D), with minor fine-grained sandstone. At Nainital syncline, siltstone and cherty/silty dolomite are the main rock types throughout the interval above surface 4, and fine-grained sandstone is relatively abundant. We infer that the source of siliciclastic sediment lay to the southeast. Thirdly, although the overall stratigraphic architecture is relatively tabular, the pinch-out towards the south-east of subtidal facies overlying surfaces 4 and 6 may be due to subtle regional onlap (Figs 4 and 5). All the rocks were disrupted by faulting and folding during the India-Eurasia collision, beginning $\approx 55$ million years ago (Powers et al., 1998; Hodges, 2000; Najman \& Garzanti, 2000).

\section{FACIES ASSOCIATIONS}

The transect constructed from measured sections and local mapping at Solan and at Nigalidhar, 


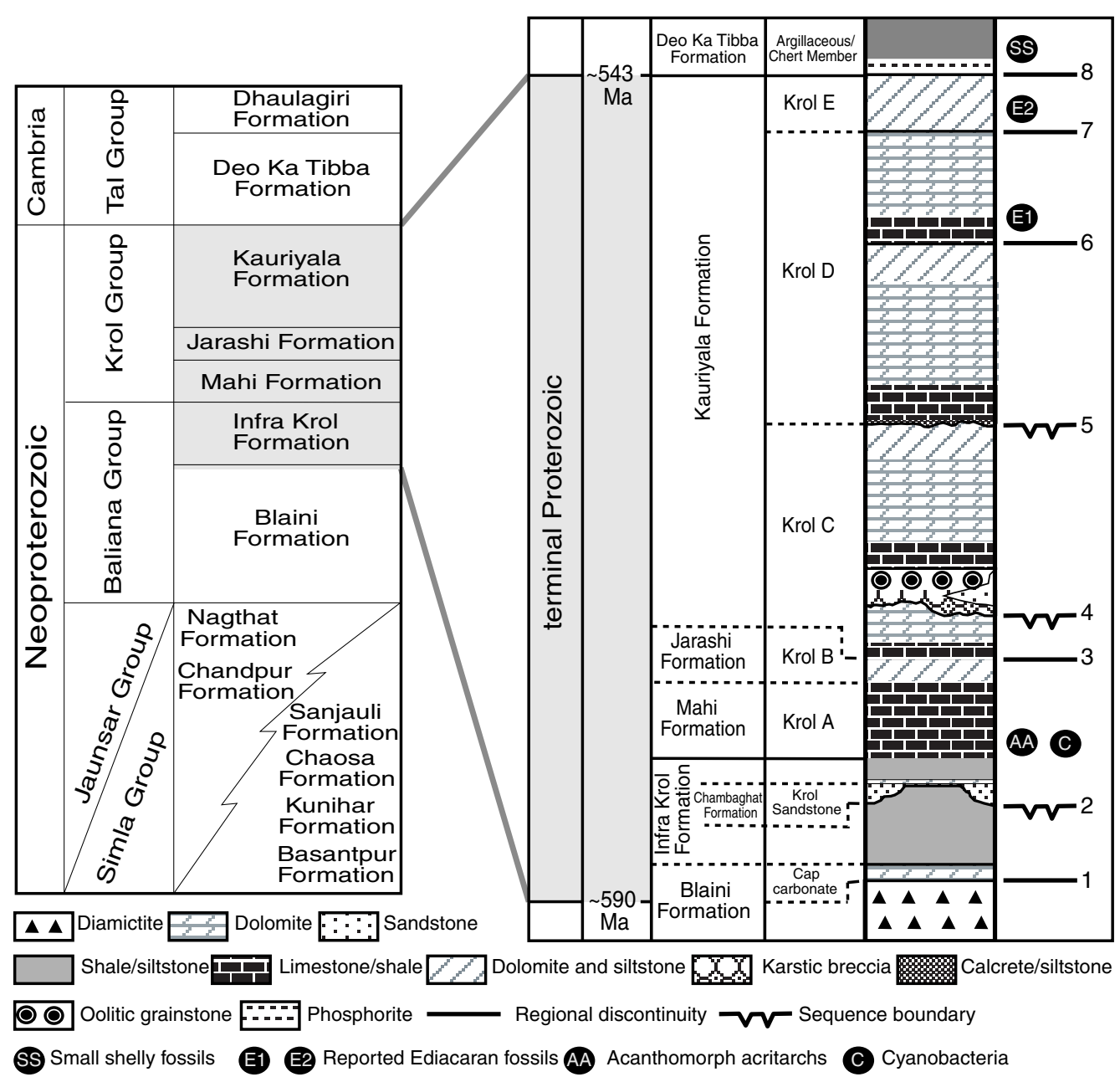

Fig. 2. Generalized Neoproterozoic stratigraphy, showing stratigraphic interval studied (shaded), stratigraphic nomenclature, reported fossil horizons and regional stratigraphic discontinuities in Infra Krol Formation and Krol Group. See Jiang et al. (2002) for details of physical stratigraphy. Palaeontological interpretations are as follows: cyanobacteria (C) and acanthomorph acritarchs (AA) from Tiwari \& Knoll (1994); Ediacaran fossils in Krol D (E1) from Shanker et al. (1997); Ediacaran fossils in Krol E (E2) from Mathur \& Shanker (1989, 1990) and Shanker et al. (1997); and small shelly fossils (SS) from Kumar et al. (1987) and Bhatt (1991).

Mussoorie, Garhwal and Nainital synclines (Fig. 4) is divided into 18 facies (Table 1). These facies are grouped into eight facies associations on the basis of palaeoenvironmental significance (Fig. 5; Table 2). A generalized reconstruction of facies distribution and platform architecture is provided in Fig. 6.

\section{Deep subtidal facies association}

The deep subtidal facies association includes three facies: calcareous shale and siltstone, interbedded shale and limestone, and muddy dolomite (Fig. 7). The muddy dolomite facies is present as a 5 to $15 \mathrm{~m}$ thick, laterally persistent unit that caps the glacial diamictite of the Blaini Formation and as a $<2 \mathrm{~m}$ thick unit that overlies surface 2 (Fig. 4). Rocks are thinly parallel laminated. In the upper part of facies units, muddy dolomite laminae are interlaminated with shale (Fig. 8A). The calcareous shale and siltstone facies constitutes the bulk of the Infra Krol Formation as well as part of the Krol D above surface 6 (Fig. 4). The facies is for the most part monotonously laminated, with locally developed layers or lenses of 2 to $5 \mathrm{~cm}$ thick, fine- to very fine-grained, cross-laminated sandstone with slightly erosional bases (Fig. 7A). The interbedded shale and limestone facies constitutes the main component of Krol A. It forms shalelimestone rhythmites (Fig. 8B) and 2 to $8 \mathrm{~m}$ thick units of alternating shale and limestone (Figs 7B and $8 \mathrm{C}$ ). The latter include 2 to $10 \mathrm{~cm}$ thick, laterally discontinuous beds of cross-laminated 


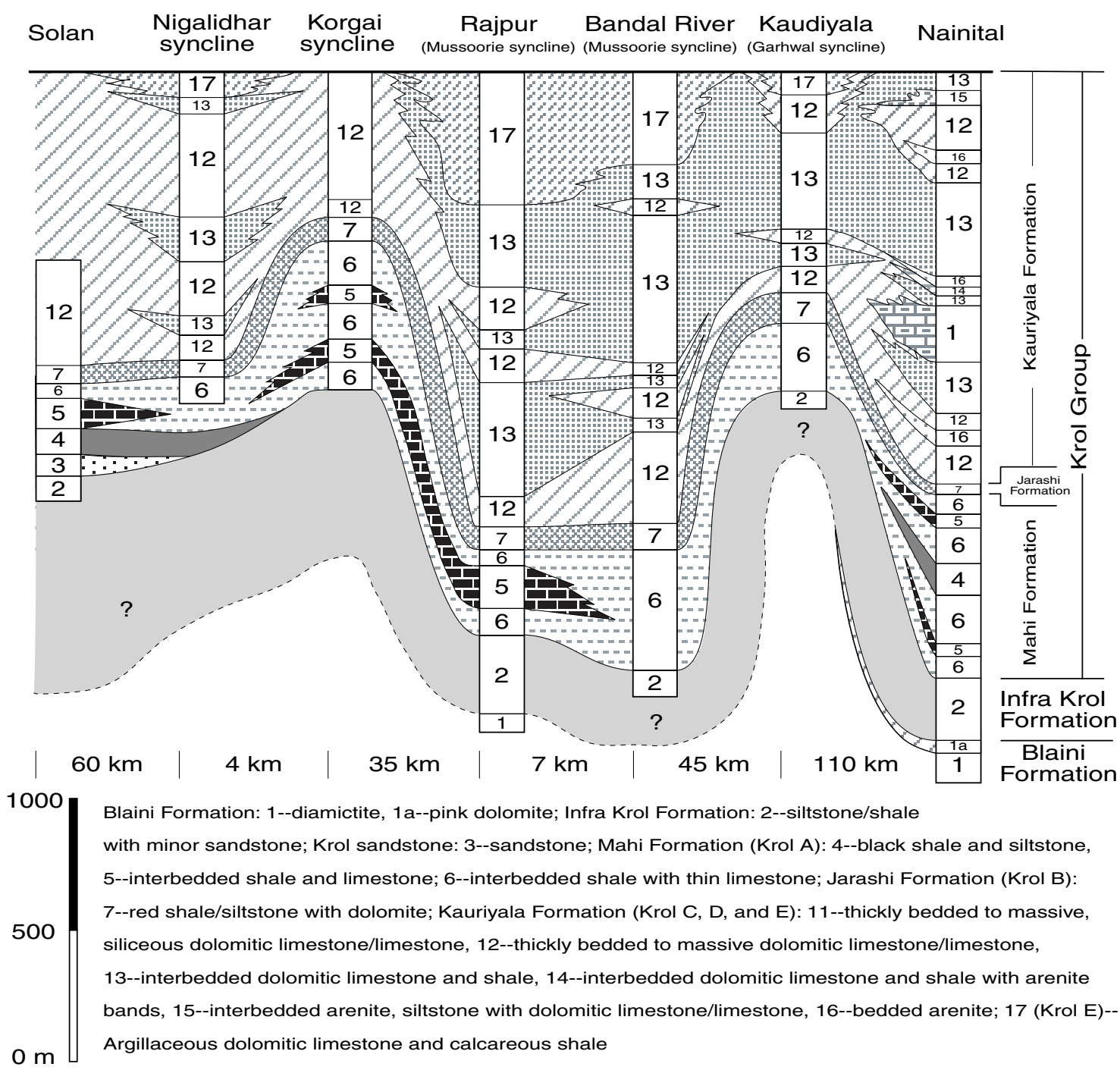

Fig. 3. Stratigraphic correlation of Infra Krol Formation and Krol Group based on lithological similarity and thickness, and implying a sedimentary basin centred on Mussoorie syncline. Redrawn from Shanker \& Mathur (1992).

fine-grained peloidal packstone/grainstone with minor erosional surfaces (Fig. 8D).

\section{Interpretation}

The above three facies are interpreted to have accumulated on a storm-influenced subtidal ramp or open shelf below fairweather wave base (Fig. 6). The presence of occasional beds and lenses of cross-laminated sandstone and grainstone/packstone and minor erosional surfaces may be indicative of storm wave activity, although features such as hummocky cross-stratification and graded bedding have not been observed. The fine-grained sandstone and carbonate grainstone are interpreted to have been derived from proximal, shallow subtidal areas of the platform, and transported seaward by storm- induced currents (Schieber, 1994, 1999), as indicated by the upward-coarsening trend recorded in measured sections.

\section{Shallow subtidal facies association}

The shallow subtidal facies association includes two mappable facies: dolograinstone/packstoneshale and dolopackstone/wackestone-siltstone (Tables 1 and 2). The first facies is present in the uppermost part of Krol A and the lowermost part of Krol C above surface 3, and the second is present mainly in the Krol D immediately above surfaces 5 and 6 (Figs 4 and 5).

The dolograinstone/packstone-shale facies makes up 1 to $6 \mathrm{~m}$ thick cycles that contain a shale-rich lower part and a carbonate-rich upper 


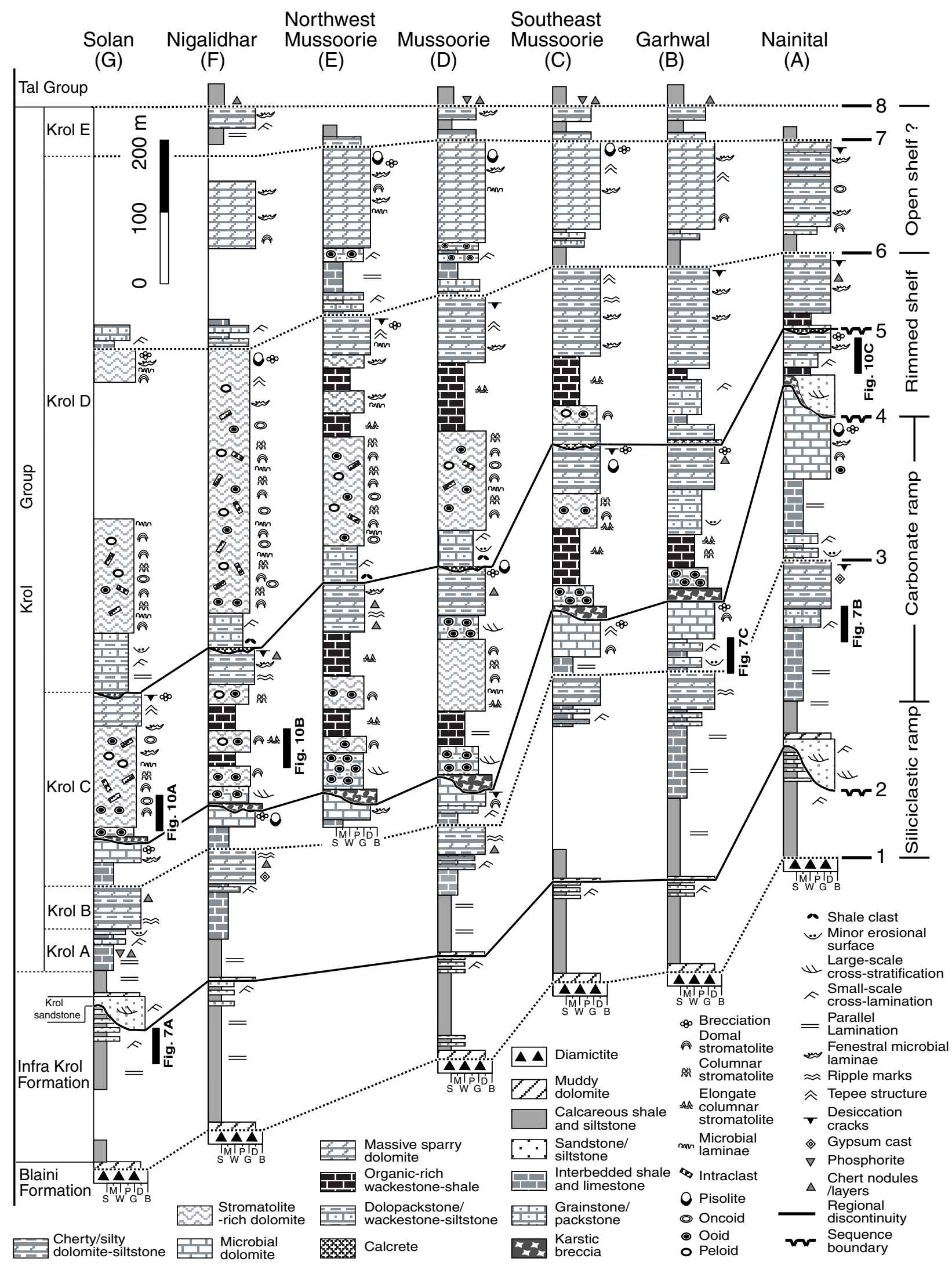

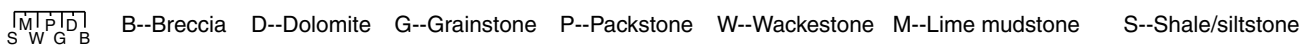




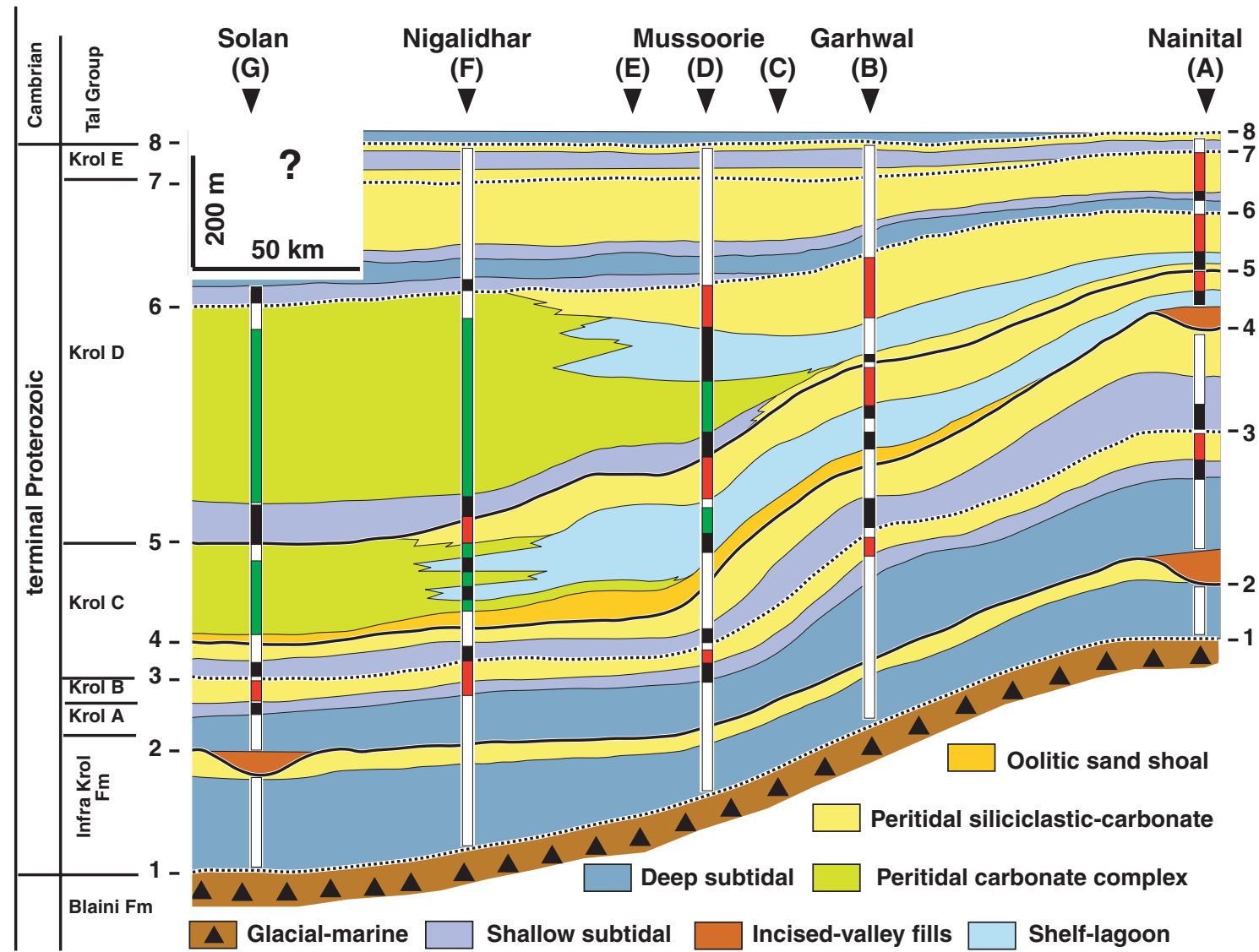

Shale-based cycles Stromatolitic cycles $\begin{aligned} & \text { Siltstone - silty/cherty } \\ & \text { dolomite alternations }\end{aligned}$ Non-cyclic intervals

Fig. 5. Interpretation of facies associations based on lithofacies and sedimentary structures summarized in Fig. 4, Table 1 and Table 2. Vertical bars show cyclic and non-cyclic intervals.

part (Fig. 7B and C). The shale-rich part is composed of greenish to dark grey, calcareous shale, with millimetre-thick lime mudstone layers or lenses. The carbonate-rich part is composed of alternating thin beds of fine-grained, oolitic-peloidal grainstone/packstone and calcareous shale (Fig. 9A and B). The grainstone/packstone layers are typically $<6 \mathrm{~cm}$ thick, laterally discontinuous and enclosed in shale (Fig. 9B). Small-scale cross-lamination, minor erosional surfaces and minor graded bedding are preserved in the grainstone/packstone layers.

The dolopackstone/wackestone-siltstone facies comprises 2 to $5 \mathrm{~m}$ thick cycles, the lower parts of which are siltstone rich and the upper parts

Fig. 4. Composite stratigraphic sections of Infra Krol Formation and Krol Group showing main lithofacies, sedimentary structures, regional stratigraphic discontinuities and their correlation along Lesser Himalaya. Sections located in Fig. 1. carbonate rich. In the siltstone-rich parts, siltstone is grey and calcareous, commonly $5-10 \mathrm{~cm}$ thick and unevenly interbedded with 0.5 to $8 \mathrm{~cm}$ thick layers of fine-grained peloidal packstone/ wackestone (Fig. 9C). Small-scale cross-lamination is present in both lithologies. The carbonate-rich upper part of each cycle is composed mainly of fine-grained, peloidal and silty packstone, with millimetre-thick, calcareous siltstone layers and lenses (Fig. 9D). Cross-lamination and minor erosional surfaces are common.

\section{Interpretation}

These two facies are interpreted to represent a shallow subtidal ramp or open shelf environment near fairweather wave base. The shale-rich and siltstone-rich parts of the two facies contain lime mudstone and wackestone layers, respectively, indicating that the fine-grained sediment was not winnowed away by wave activity. However, the presence of cross-lamination and erosional surfaces suggests a modest level of wave action, 


\section{A Rimmed shelf}

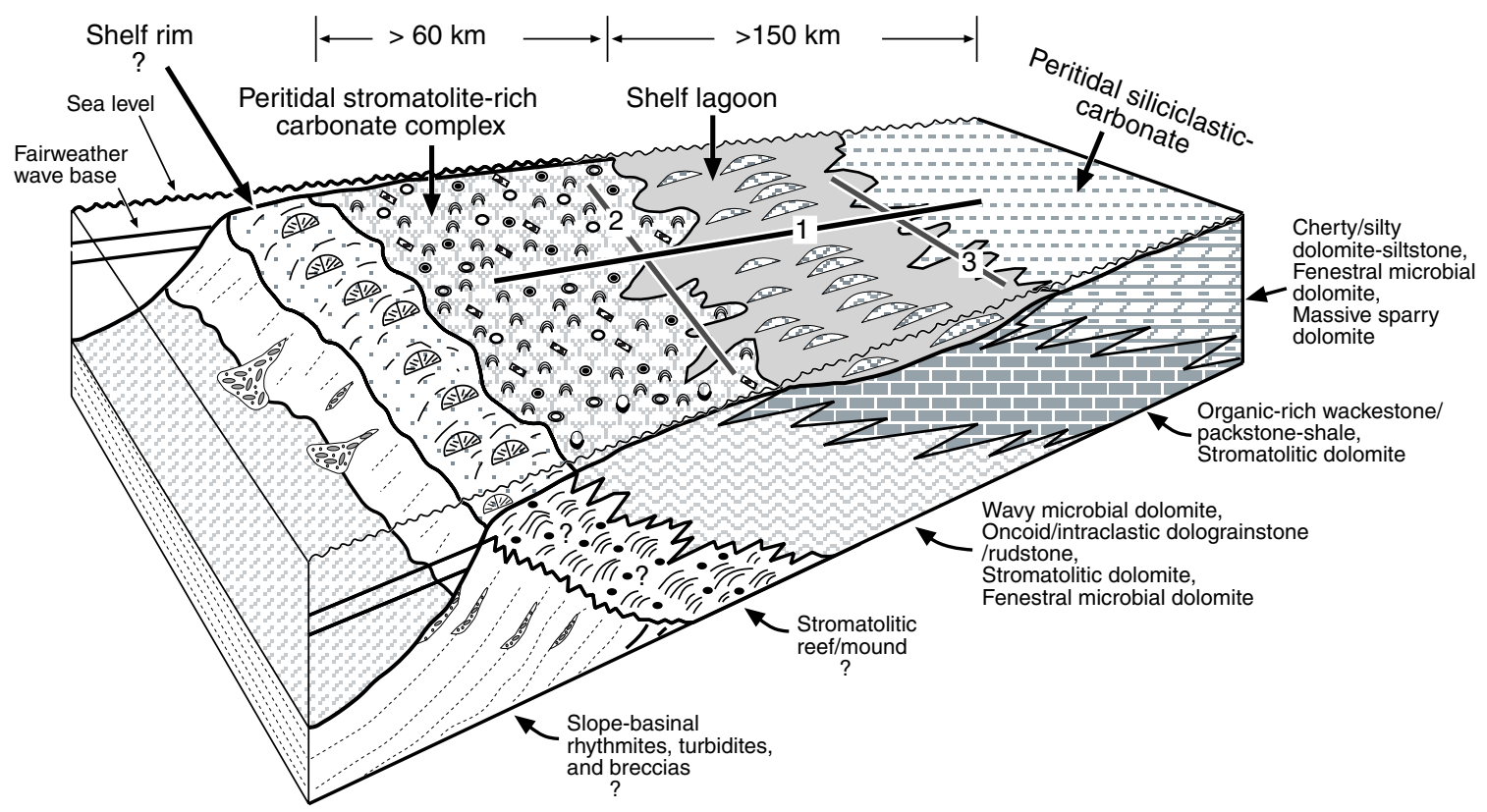

\section{B Ramp}

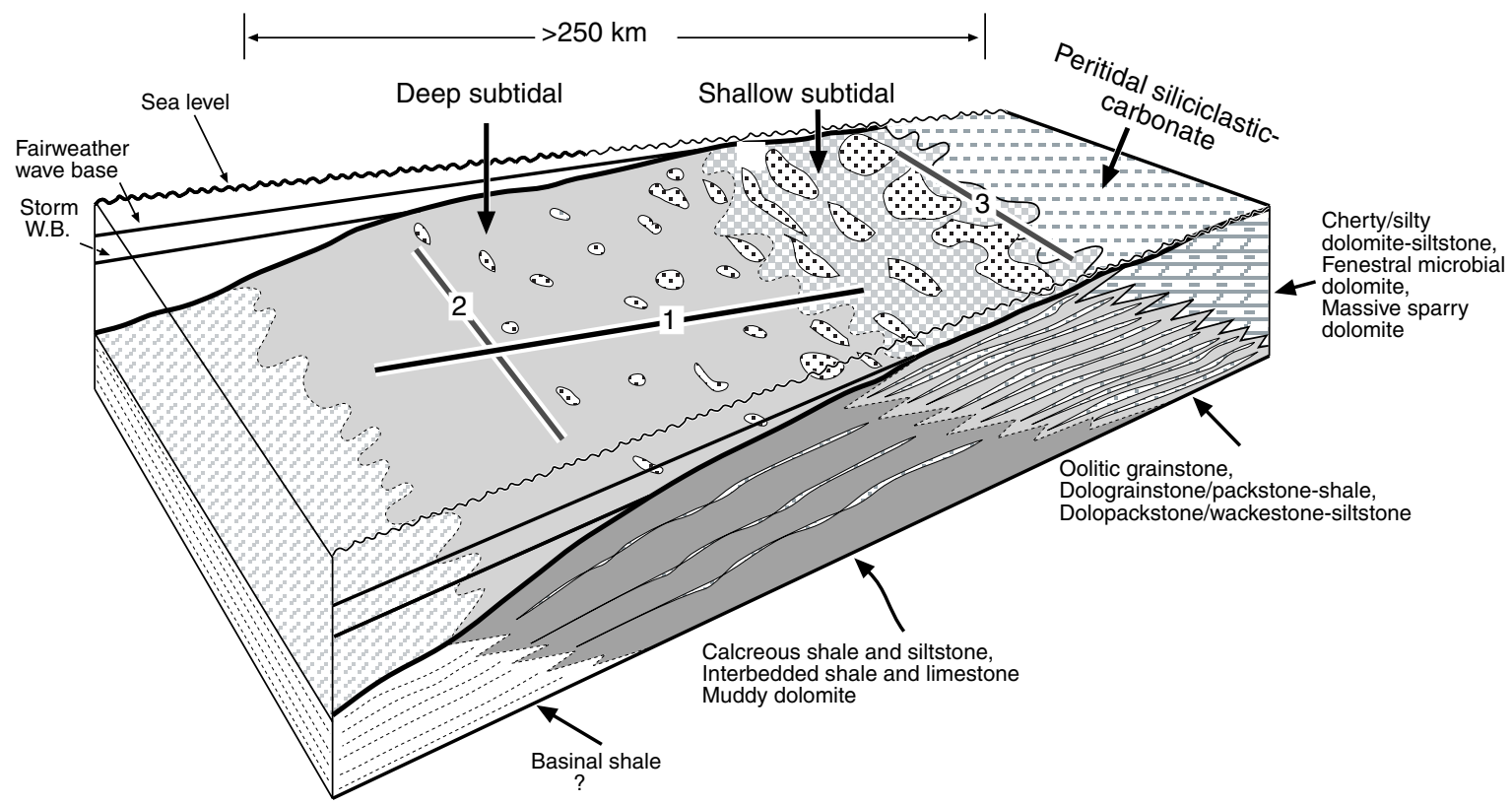

Fig. 6. Palaeoenvironmental reconstruction of geometry and facies distribution for a peritidal rimmed shelf (A) and ramp (B) of the Krol platform. Numbered lines show configuration of regional palaeogeographic reconstructions: 1 corresponds to profile shown in Fig. 5 (not necessarily perpendicular to depositional strike); 2 and 3 are interpretations implied by previous publications (e.g. Singh, 1980a,b; Singh \& Rai, 1980).

perhaps storm induced. Hence, they may represent environments below fairweather wave base in which shale and siltstone could accumulate from suspension, with carbonate being introduced during storms. The carbonate-rich parts of the two facies consist mainly of grainstone and packstone, with abundant cross-lamination and erosional surfaces. Grainstones are inferred to have accumulated in wave-influenced environments above fairweather wave base, and pack- 


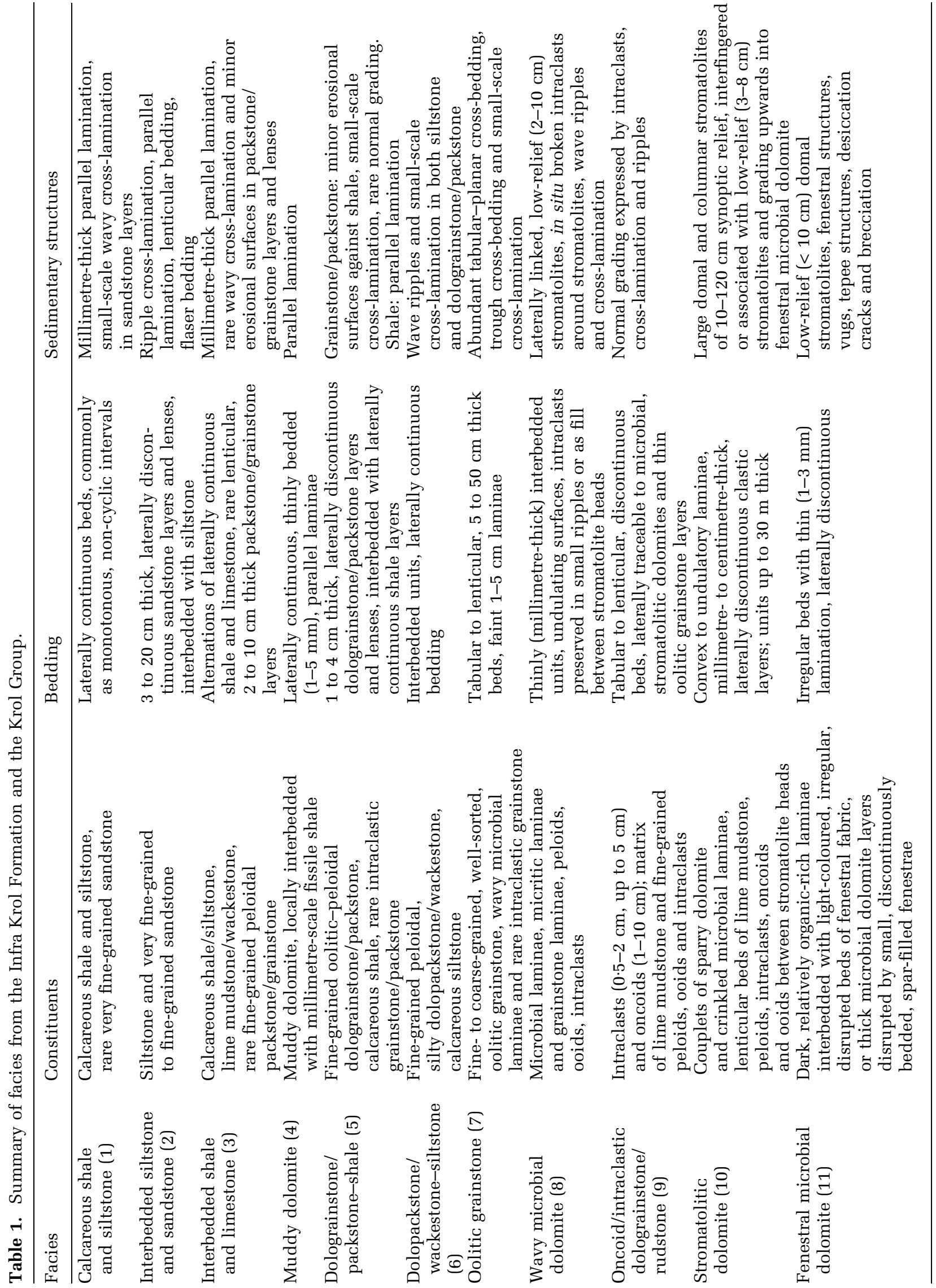




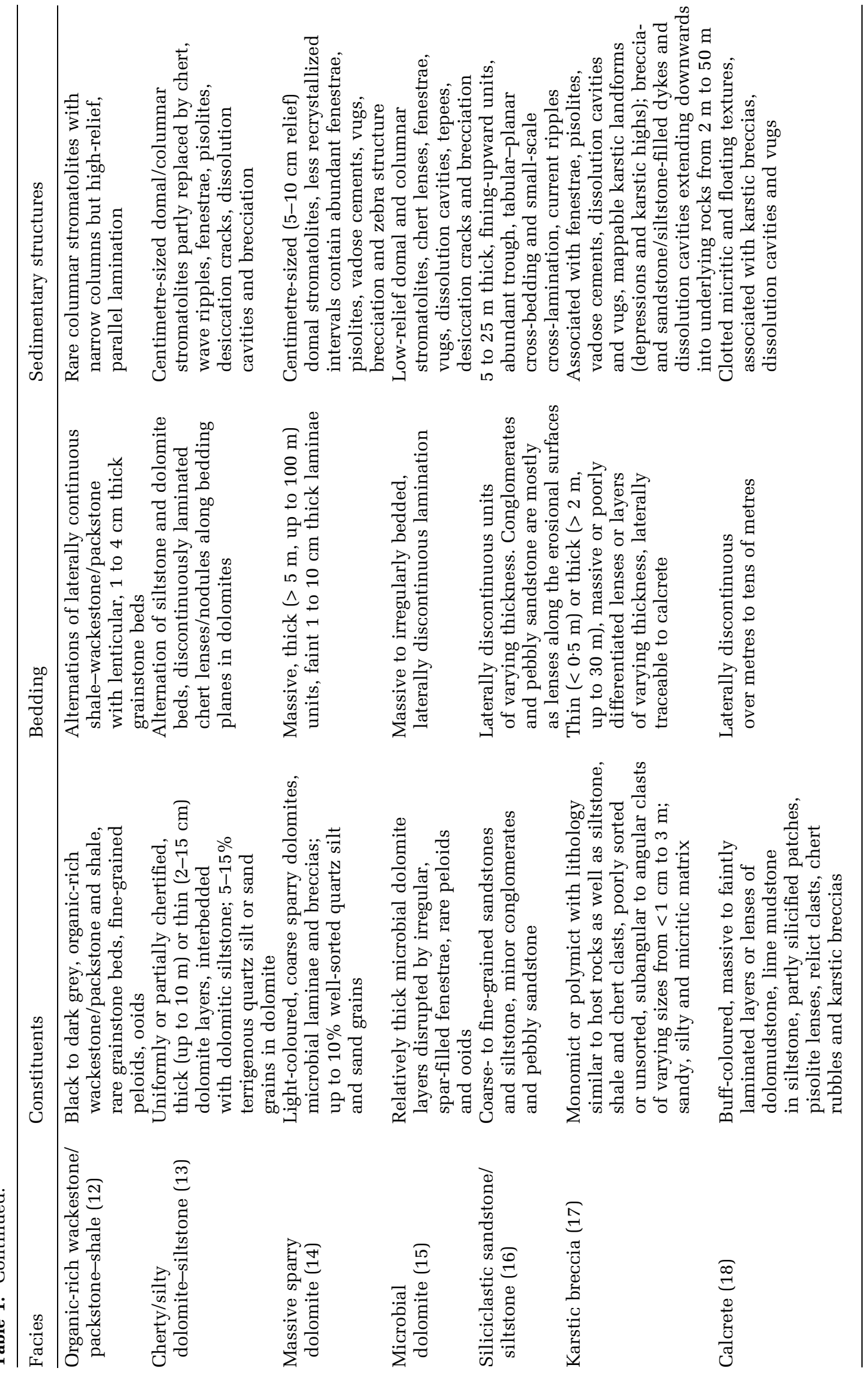




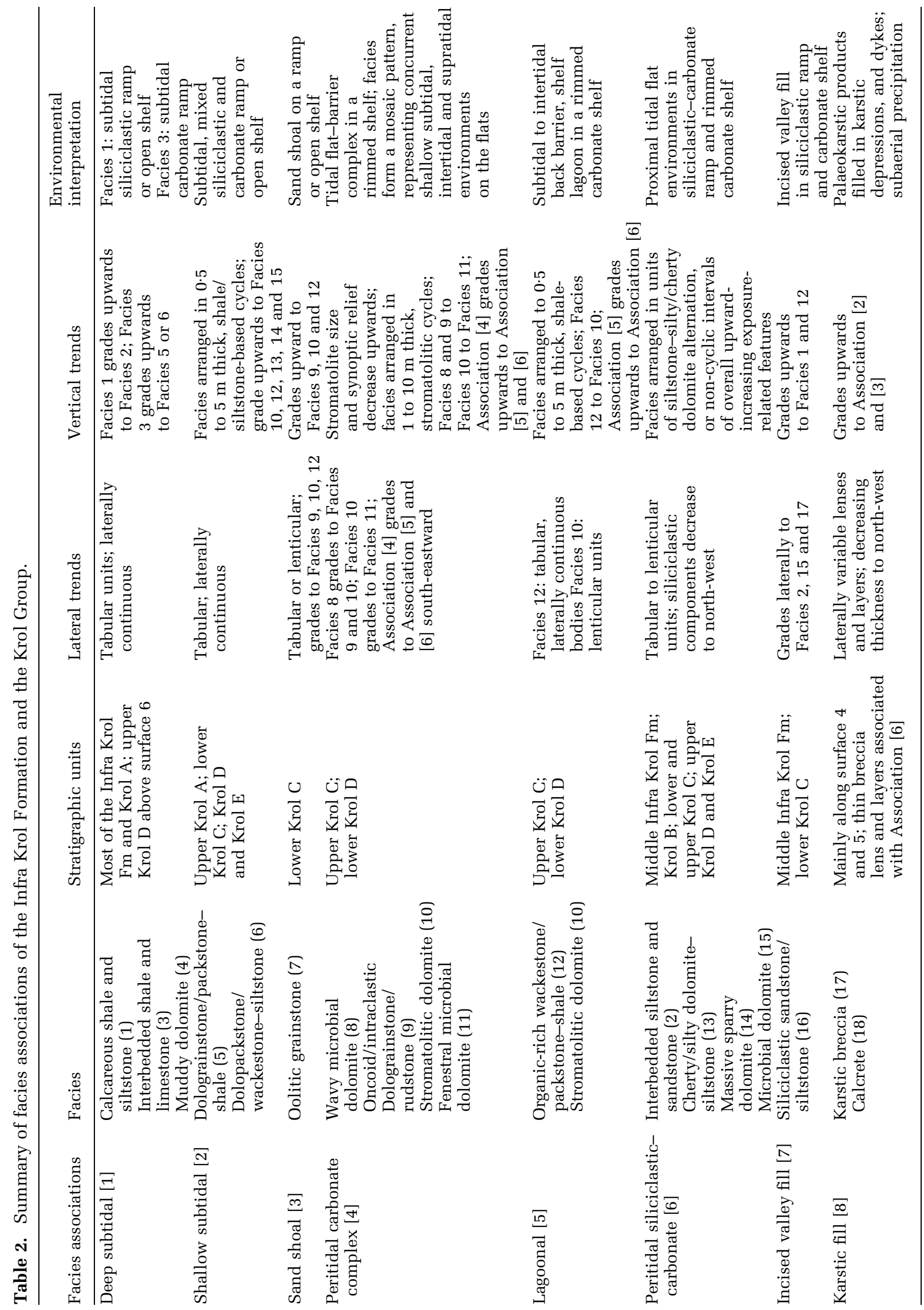


A

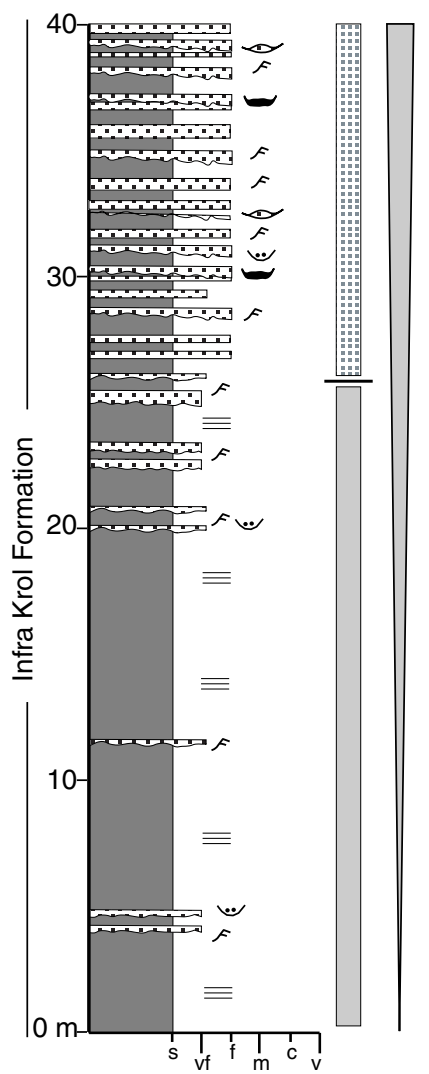

B

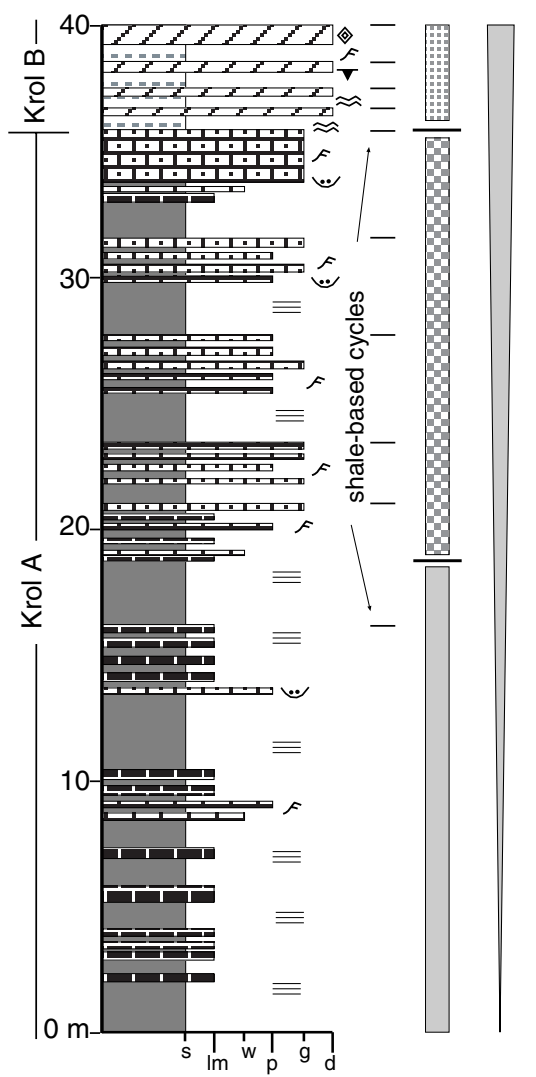

C

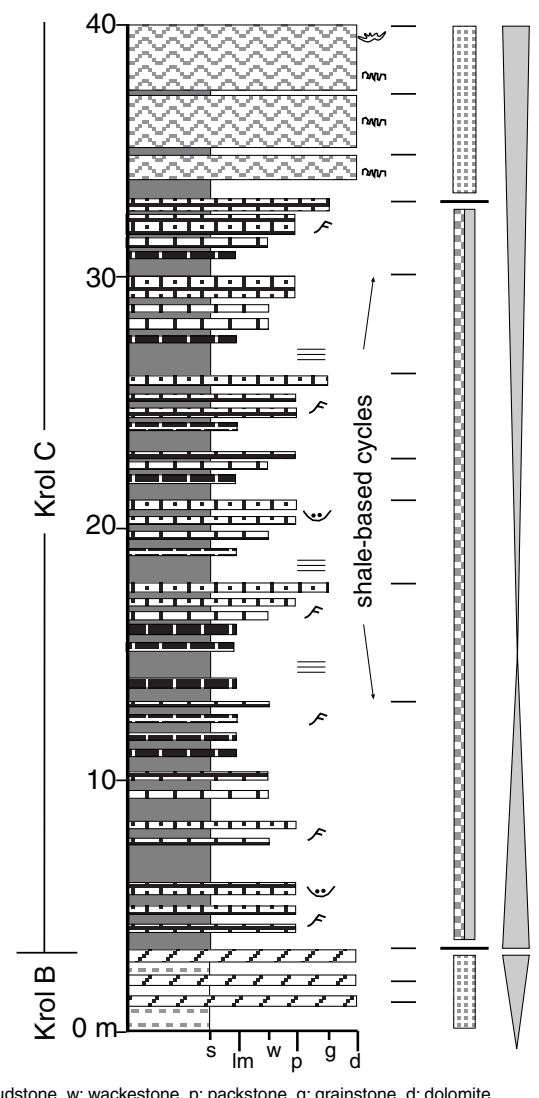

/

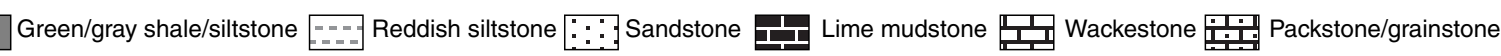
20 Cherty/silty dolomite $\approx$ Lenticular bedding $\approx$ Ripple marks $\mathbf{V}$ Desiccation cracks $\diamond$ Gypsum cast mon Microbial laminae m Fenestral structures

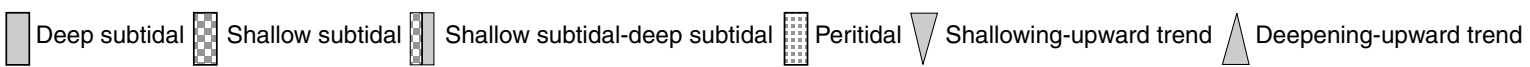

Fig. 7. Representative stratigraphic sections of deep subtidal, shallow subtidal and peritidal facies associations. (A) Deep subtidal calcareous shale/siltstone facies to peritidal interbedded sandstone and siltstone facies of middle Infra Krol Formation. Partial measured section at Deoghat, near Solan. (B) Deep subtidal interbedded shale and limestone facies to shallow subtidal dolograinstone/packstone-shale facies (Krol A), to peritidal cherty/silty dolomite-siltstone facies (Krol B). Partial measured section along south limb of Nainital syncline, north of Runsi village. (C) Peritidal cherty/silty dolomite-siltstone (Krol B) to transitional deep to shallow subtidal dolograinstone/packstone-shale facies, to peritidal microbial dolomite facies (Krol C). Partial measured section at Kaudiyala, north limb of Garhwal syncline. See Fig. 4 for stratigraphic location.

stones may have deposited below fairweather wave base. The close association of grainstone and packstone (Fig. 7B) indicates that environments were not far from the fairweather wave base, different from the deep subtidal facies association described above. Carbonate particles may have been derived from local shoals or bars (Fig. 6B). The alternation of shale/siltstone-rich and carbonate-rich hemi-cycles suggests systematic variations in palaeowater depth and fluctuations in the supply of terrigenous clastic sediment (cf. Holland \& Patzkowsky, 1998).

\section{Sand shoal association}

The sand shoal facies association consists of fineto coarse-grained oolitic grainstone with subordinate wavy microbial laminae and rare intraclastic beds and lenses (Tables 1 and 2). We separate this facies association from relatively thin oolitic grainstone layers in other facies associations because it forms an interval as much as $50 \mathrm{~m}$ thick in the lower part of Krol C above surface 4 (Figs 4 and 5). Grainstone beds are typically $5-50 \mathrm{~cm}$ thick, separated by thin $(<5 \mathrm{~cm})$ faint 

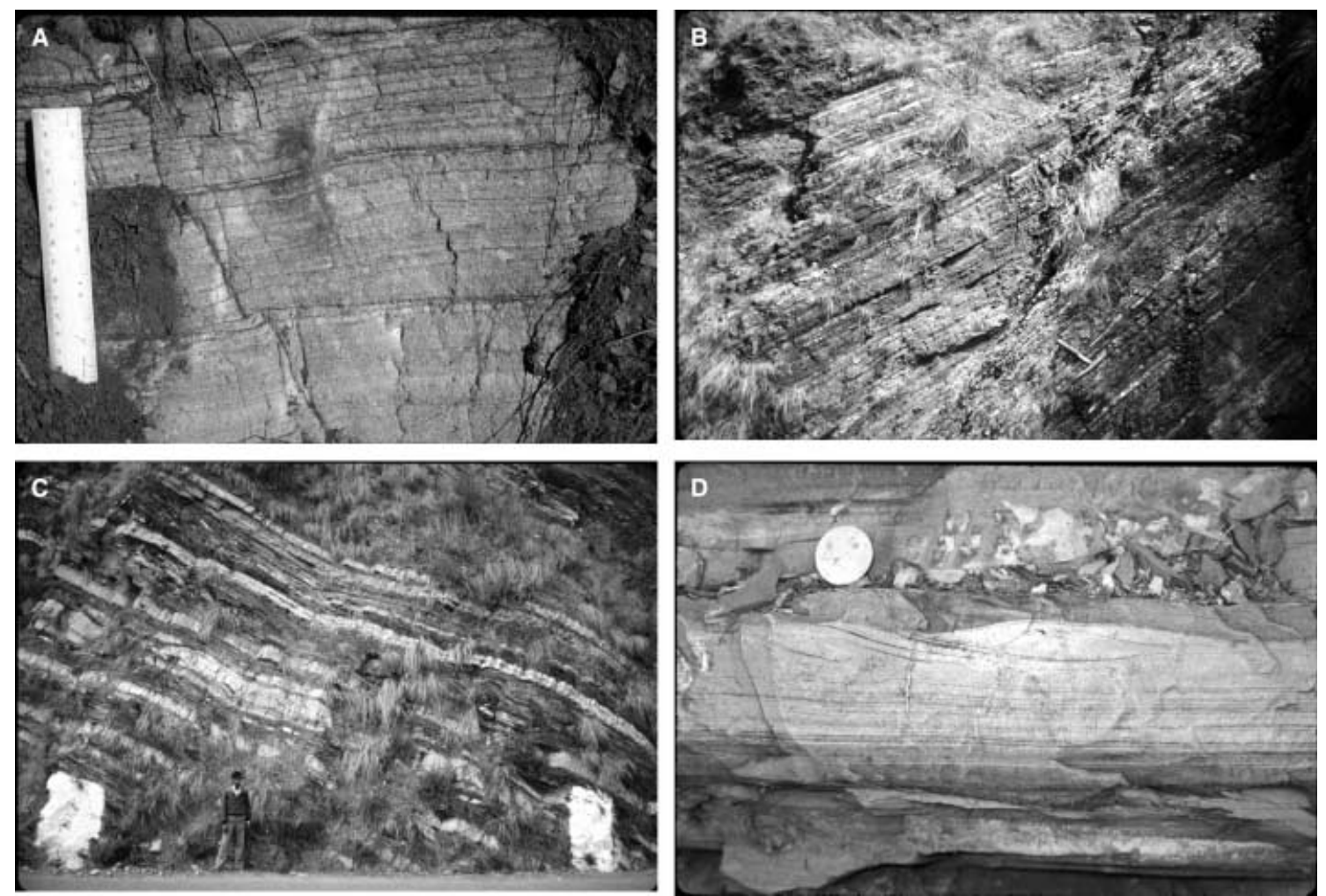

Fig. 8. Deep subtidal facies association. (A) Muddy dolomite facies capping glacial diamictites of Blaini Formation, showing thinly interbedded muddy dolomite laminae and fissile shale laminae. From Dhanaulti, Mussoorie syncline. (B) Thinly laminated shale-limestone rhythmites of middle Krol A, Nainital syncline. (C) Interbedded shale and limestone facies expressed as cycles with alternating shale-rich part and limestone-rich part, upper Krol A, Solan. (D) Small-scale cross-lamination in fine-grained peloidal grainstone (detail of limestone in C). Scales: A (metre), $15 \mathrm{~cm}$; B (hammer), $32 \mathrm{~cm}$; C (field assistant), $1.7 \mathrm{~m}$ high; and D (coin), $1.8 \mathrm{~cm}$ in diameter.

microbial laminae and intraclastic beds and lenses (Fig. 9E). Decimetre-scale tabular and trough cross-stratification characterizes most oolitic beds, although they are locally cryptic. Ooids display considerable size variation between beds, but grains within an individual bed are commonly well sorted. Ooids are typically $0 \cdot 3-1.5 \mathrm{~mm}$ in diameter, but as large as $2.5 \mathrm{~mm}$ in trough cross-stratified sets. Grading and poor sorting are observed locally in the latter. Most ooids have cores composed of one or more quartz silt grains. In the case of some large ooids, cores are microbial or composed of micritic intraclasts. Concentric coatings of individual ooids range in thickness from $<0.01$ to $0.05 \mathrm{~mm}$. Ooid shape ranges from nearly spherical to elongate (2:1 ratio of apparent long and short dimensions) to irregular (Fig. 9F).

\section{Interpretation}

The thick grainstone interval in Krol C is interpreted as a subtidal carbonate sand shoal subjected to sustained high-energy conditions. The abundance of quartz silt grains as ooid nuclei indicates a ready source of siliciclastic particles at a newly submerged ramp or open shelf developed on a karstic surface. The interlayering of grainstone with faint, wavy microbial laminae suggests spatial and temporal variations in the intensity and frequency of wave action (Sweet \& Knoll, 1989). The presence of trough cross-stratification suggests migration of current-generated bedforms in a broad, shallow subtidal environment.

\section{Peritidal carbonate complex}

The peritidal carbonate complex includes four lithofacies: wavy microbial dolomite, oncoid and intraclastic dolograinstone/rudstone, stromatolitic dolomite and fenestral microbial dolomite (Tables 1 and 2). These facies together form thick, stromatolite-rich carbonate units in the Krol C and Krol D at Mussoorie and Nigalidhar synclines and at Solan (Figs 4 and 5). Facies are commonly arranged into 2 to $12 \mathrm{~m}$ thick cycles that begin with wavy microbial

(C) 2003 International Association of Sedimentologists, Sedimentology, 50, 921-952 

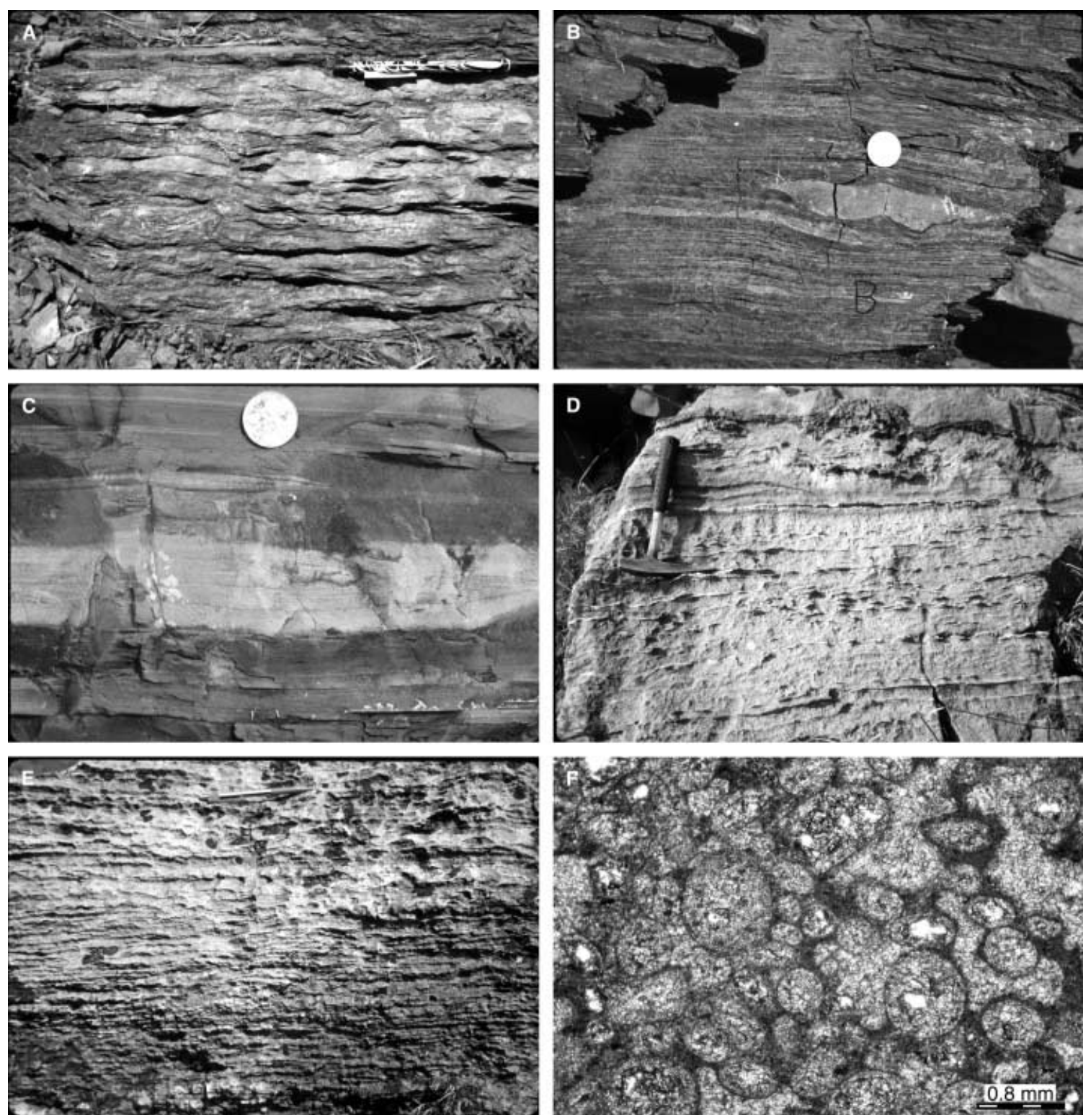

Fig. 9. Facies of shallow subtidal and sand shoal facies associations. (A) Interbedded calcareous shale and finegrained, oolitic-peloidal grainstone/packstone, lower part of Krol C, Kaudiyala section, Garhwal syncline. (B) Lenticular peloidal grainstone interbedded with laminated calcareous shale, lower part of Krol C, Kaudiyala section, Garhwal syncline. (C) Cross-laminated, fine-grained peloidal packstone interbedded with calcareous siltstone, basal part of Krol D above surface 5, south cliff of Krol Hill, Solan. (D) Cross-laminated, fine-grained, peloidal and silty packstone and calcareous siltstone. Siltstone layers are chertified and expressed by positive relief on weathered surface. Basal part of Krol D above surface 5, south cliff of Krol Hill, Solan. (E) Oolitic grainstone with faint microbial laminae, Krol C above surface 4, Nigalidhar syncline. (F) Oolitic grainstone from (E). Scales: A and E (pencil), $14.5 \mathrm{~cm}$; B (coin), $1.8 \mathrm{~cm}$ in diameter; C (coin), $2 \mathrm{~cm}$ in diameter; D (hammer), $32 \mathrm{~cm}$.

dolomite, pass upwards into domal and columnar stromatolites and are capped with fenestral microbial dolomite (Fig. 10A). Oncoid and intraclastic dolograinstone/rudstone is present throughout each cycle, but is generally more abundant at the base and in the lows between stromatolite heads. Large stromatolites in places pass laterally into smaller stromatolites, ooid/ peloid-rich microbial dolomite or, less commonly, into intraclastic rudstone. As a consequence, the facies forms a mosaic of microbial laminae and stromatolite-rich carbonate rather than a series of stacked sheets. Individual cycles and their component facies cannot be traced laterally more than a few tens to hundred of metres. 
A

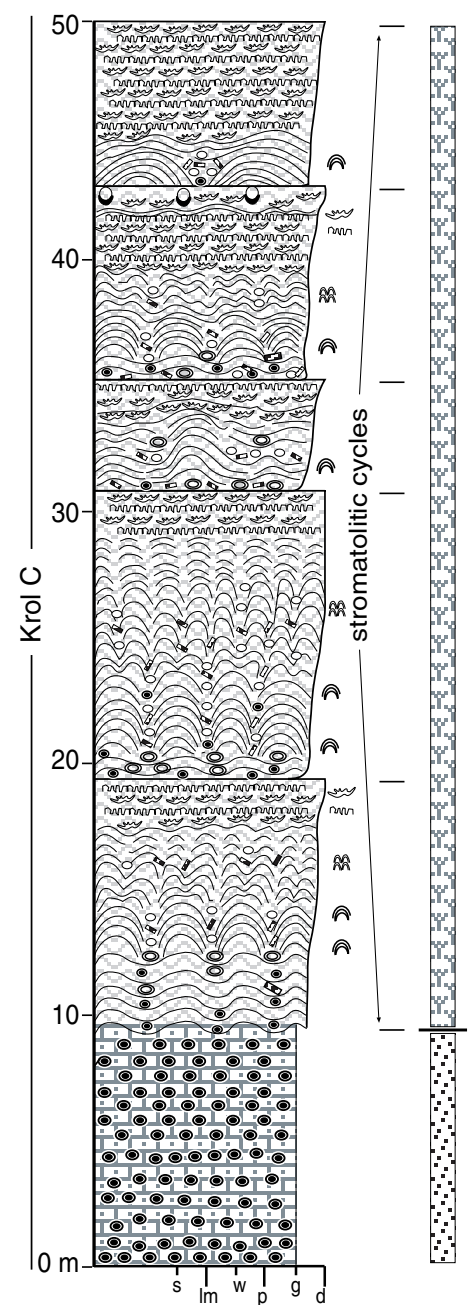

B

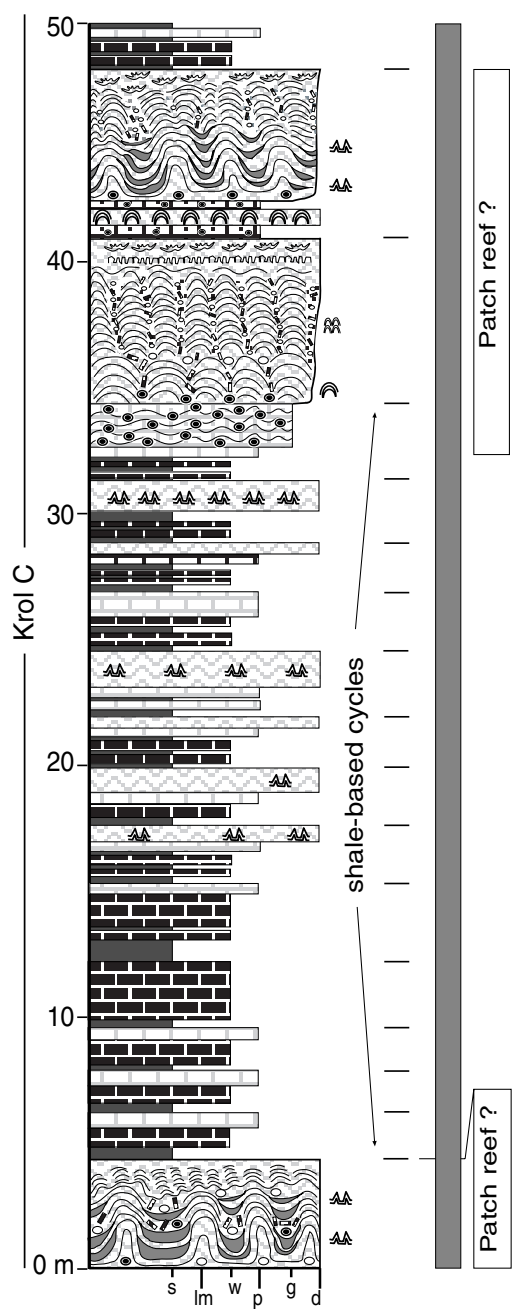

C

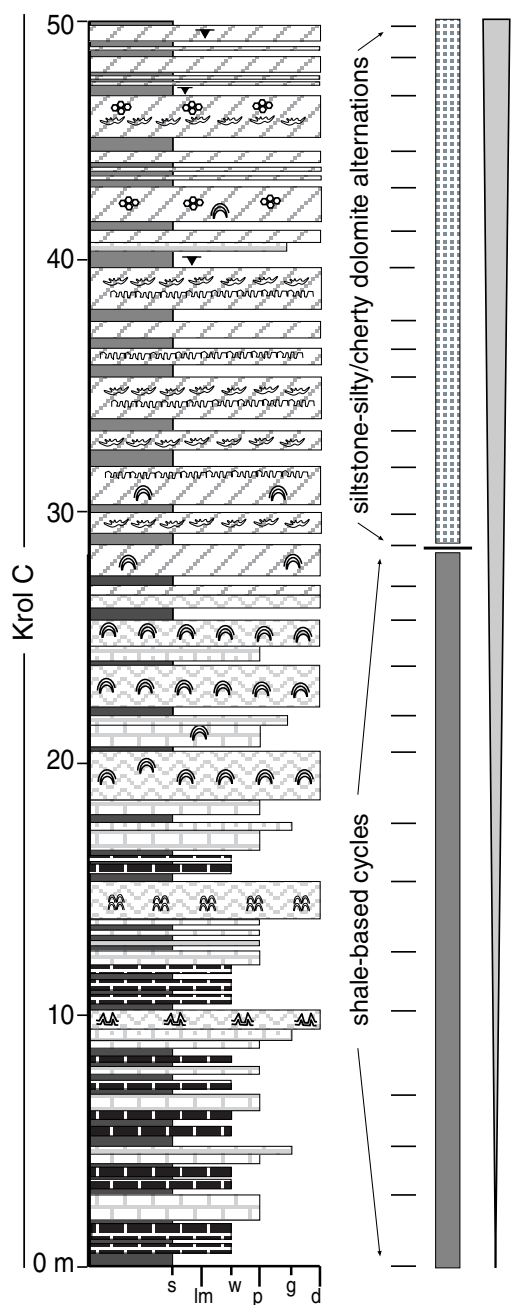

s: shale/siltstone, lime mudstone, w: wackestone, p: packstone, g: grainstone, d: dolomite

\footnotetext{
$\square$ Organic-rich shale $\square$ Siltstone 甹 Organic-rich wackestone $\square$ Packstone $\square$ Grainstone $\square$ Cherty/silty dolomite

Microbial dolomite 2 Wavy microbial laminae mur Microbial laminae my Fenestral microbial laminae $\boldsymbol{\sim}$ Desiccation cracks ค Domal stromatolites Columnar stromatolites Elongate columnar stromatolites ๑ Ooids oPeloids o Oncoids Intraclasts $\odot$ Pisolites

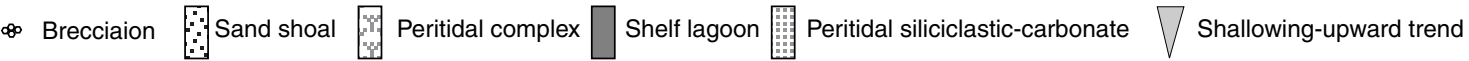

Fig. 10. Representative stratigraphic sections of peritidal complex, lagoonal and peritidal carbonate-siliciclastic facies associations. (A) Carbonate sand shoal to peritidal stromatolite-rich facies, Krol C above surface 4; partial measured section along south cliff of Krol Hill, Solan. (B) Organic-rich wackestone/packstone-shale and stromatolite-rich facies of lagoonal setting, Krol C above surface 4, Nigalidhar syncline. (C) Organic-rich wackestone/ packstone-shale and stromatolitic dolomite facies of lagoonal setting to peritidal cherty/silty dolomite-siltstone facies, Krol C above surface 4, Nainital syncline. See Fig. 4 for stratigraphic location.

Wavy microbial dolomite is composed of 1 to $10 \mathrm{~cm}$ thick beds of grey microbial laminae (1-10 mm thick) and dark micritic laminae (0.5-2 mm thick), interstratified with 2 to $5 \mathrm{~cm}$ thick beds of fine-grained oolitic/peloidal/intraclastic dolograinstone. Some microbial laminae contain fine-grained peloids, $0 \cdot 1-0 \cdot 3 \mathrm{~mm}$ in diameter. Dolograinstone layers contain abundant cross-lamination and erosional surfaces (Fig. 11A and $\mathrm{B}$ ). Ooids are $0 \cdot 2-0 \cdot 8 \mathrm{~mm}$ in diameter, with silt or micrite grains in the centre and concentric, intercalated organic-rich and inorganic coatings. Peloids are micritic grains $0 \cdot 1-0 \cdot 3 \mathrm{~mm}$ in diameter. Intraclasts are angular to subangular particles $0 \cdot 5-3 \mathrm{~mm}$ in diameter, and are commonly present as a minor component in dolograinstone. 

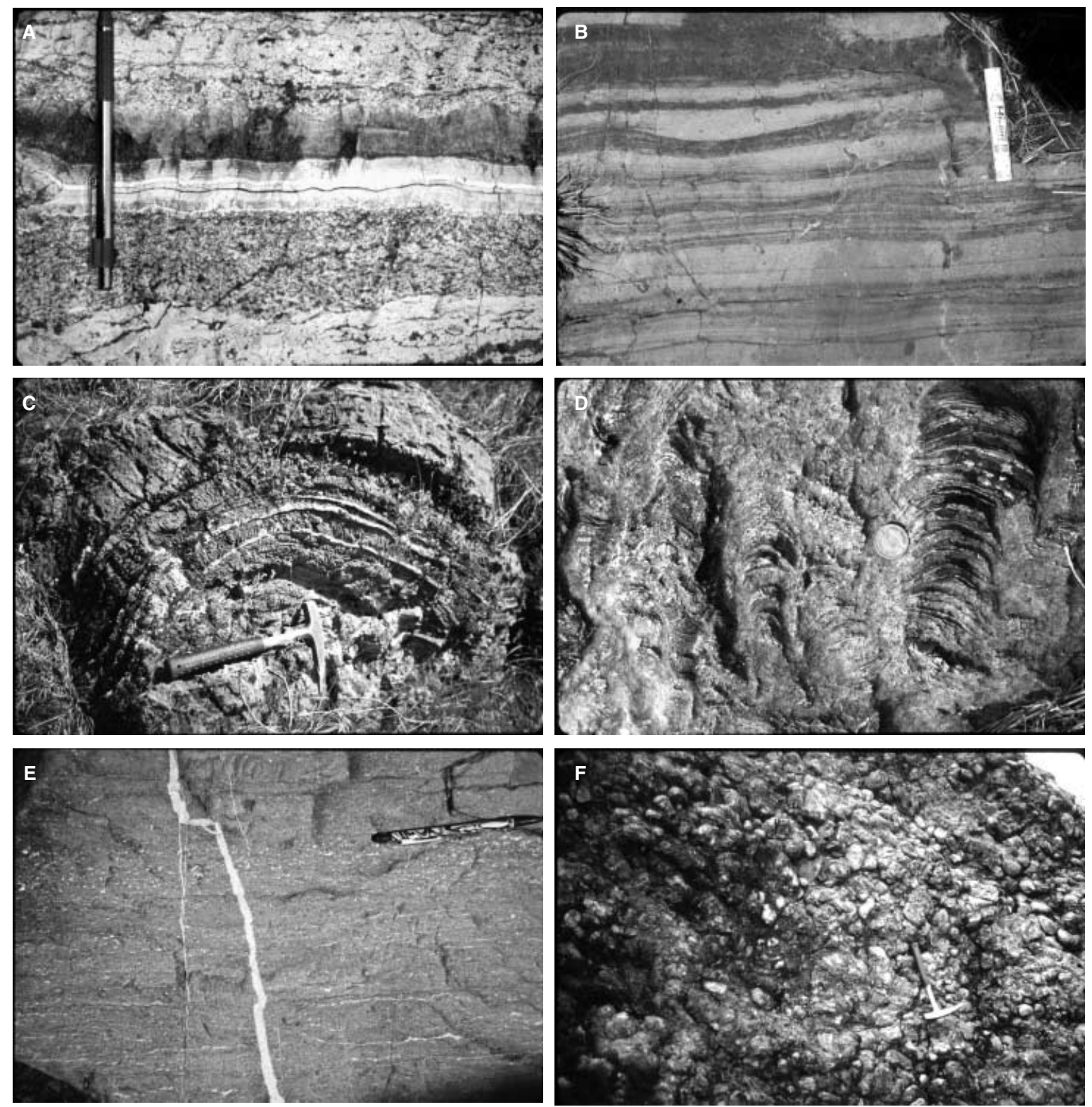

Fig. 11. Facies of peritidal carbonate complex. (A) Wavy microbial dolomite, composed of dark grey microbial laminae and light-coloured, fine-grained peloidal grainstone laminae. Erosional surfaces below grainstone layers, Krol C above surface 4, Nigalidhar syncline. (B) Thinly interbedded microbial and micritic laminae (light colour) and intraclastic grainstone layers, with erosional surfaces below grainstone layers, Krol C above surface 4, Nigalidhar syncline. (C) Large domal stromatolite bioherm, Krol C above surface 4, Solan. (D) Columnar stromatolite with peloids, ooids, intraclasts and oncoids in troughs between stromatolite heads, Krol C above surface 4, Solan. (E) Fenestral microbial dolomite composed of micritic microbial laminae and discontinuous fenestral fabric (light colour), Krol C above surface 4, Solan. (F) Plan view of oncoid/intraclastic grainstone consisting of large, concentric oncoids in a fine-grained grainstone matrix, Krol C above surface 4, Solan. Scales: A and E (pencil), 14.5 cm; B (pen), $12 \mathrm{~cm}$; C and F (hammer), $32 \mathrm{~cm}$; and D (coin), $2 \mathrm{~cm}$ in diameter.

Low-relief $(2-10 \mathrm{~cm})$ laterally linked stromatolites are present in some intervals, with intraclasts forming lenses between stromatolite heads.

Stromatolitic dolomite contains abundant stromatolites of varying shapes and sizes. Large domal stromatolites (Fig. 11C) are typically unlinked bioherms with up to $120 \mathrm{~cm}$ synoptic relief, grading laterally into low-relief domal stromatolites or wavy microbial dolomite. Columnar stromatolites are commonly linked, with ooids, peloids, oncoids and intraclasts present in lows between stromatolite heads (Fig. 11D). 
Carbonate mud content is very low. Within particular cycles, large, isolated domes coalesce upwards into linked or unlinked columns with increased branching, decreased diameter and decreased synoptic relief (Fig. 10A).

Fenestral microbial dolomite consists of thinly laminated, dark grey, relatively organic-rich layers interbedded with light-coloured, irregular, disrupted laminae with fenestral fabric (Fig. 11E), or consists of thick layers disrupted by discontinuously bedded, spar-filled fenestrae. Microbial laminae form metre-thick units that commonly cap stromatolitic cycles (Fig. 10A). Vugs, desiccation cracks, tepee structures, pisolites and karstic breccia occur in this facies.

Oncoid and intraclastic dolograinstone/rudstone forms lenticular beds, commonly associated with microbial and stromatolitic dolomite and oolitic grainstone. Oncoids are 1-10 cm in diameter, with nuclei of fragments of underlying strata and microbial, organic-rich coatings (Fig. 11F). Intraclasts are typically angular to subangular, varying in size from $0.5 \mathrm{~mm}$ to $5 \mathrm{~cm}$ and are cemented by coarse spar. Normal grading and nearly in situ clasts of stromatolites are found in troughs between stromatolite heads.

\section{Interpretation}

Wavy microbial dolomite is interpreted to have accumulated in a moderate- to high-energy shallow subtidal to lower intertidal environment. This is indicated by the presence of low-relief stromatolites, abundant cross-lamination and grainstone with allochems such as peloids, ooids and intraclasts. Microbial laminae containing fine-grained peloids are interpreted to have developed by a combination of cement precipitation and binding of particles by microbial mats (Burne \& Moore, 1987; Feldmann \& McKenzie, 1998). Grainstone/packstone layers and lenses are interpreted to have formed in a storm-influenced setting, in which ooids and oncoids were transported from adjacent shoals, and intraclasts were reworked from a lithified or partially lithified sea floor. The repeated evolution of stromatolites from large, isolated domes to linked or unlinked columns with increased branching, decreased diameter and decreased synoptic relief (Fig. 10A) is interpreted to represent a transition from a relatively undisturbed, subtidal environment to an environment influenced by waves (cf. Southgate, 1989; Sami \& James, 1993). The presence of fenestral microbial laminae in the upper stromatolitic layers indicates stromatolite growth at times into low-energy, intertidal to supratidal environments (e.g. Southgate, 1989). Fenestral microbial laminae are thought to have formed through the binding of micrite by microbial mats, and to have been preserved as a result of early filling by cement or micrite lithification (cf. Shinn, 1986; Sami \& James, 1994). The presence of desiccation cracks, tepee structures, pisolites and karstic breccia is indicative of upper intertidal to supratidal environments (Pratt et al., 1992). Associated oncoids and intraclasts are interpreted to have formed by storm wave erosion and reworking of stromatolites, microbial laminites and relicts of oncoids in shallow-water environments. The generation and transportation of these grains may have resulted from the combination of storm and fairweather currents because stromatolite intraclasts would have been derived with difficulty under fairweather conditions, given the sparry cements that may represent early sea-floor cementation (cf. Sami \& James, 1994).

The peritidal complex grades towards the south-east into lagoonal facies (Figs 5 and 6). It may have acted as a marginal barrier separating the shelf lagoon from the open ocean. Comparable examples have been documented from three Palaeoproterozoic deposits, the Pethei Group of north-west Canada (Sami \& James, 1994), the Transvaal Supergroup of southern Africa (Beukes, 1987) and the Rocknest platform in north-west Canada (Grotzinger, 1986a,b, 1989b).

\section{Lagoonal facies association}

The lagoonal facies association includes two main facies: organic-rich wackestone/packstoneshale and stromatolitic dolomite (Tables 1 and 2). The facies are present in the Krol C above surface 4 and in Krol D above surface 5. Regionally, the facies association is thickest at Nigalidhar and Mussoorie synclines, and comparatively thin at Garhwal and Nainital synclines. It interfingers with the peritidal carbonate complex described above (Fig. 5).

The two facies are commonly arranged as 0.5 to $5 \mathrm{~m}$ thick shale-based cycles or 5 to $10 \mathrm{~m}$ thick stromatolitic cycles (Fig. 10B and C). Shale-based cycles are composed of organic-rich shale and wackestone overlain by oolitic/peloidal packstone and stromatolitic dolomite (Fig. 12A). The stromatolitic facies is similar to that described in the peritidal complex, but the stromatolites are characterized by narrower columns, greater synoptic relief, locally elongated heads and higher lime mudstone content (Fig. 12B and C). Some 

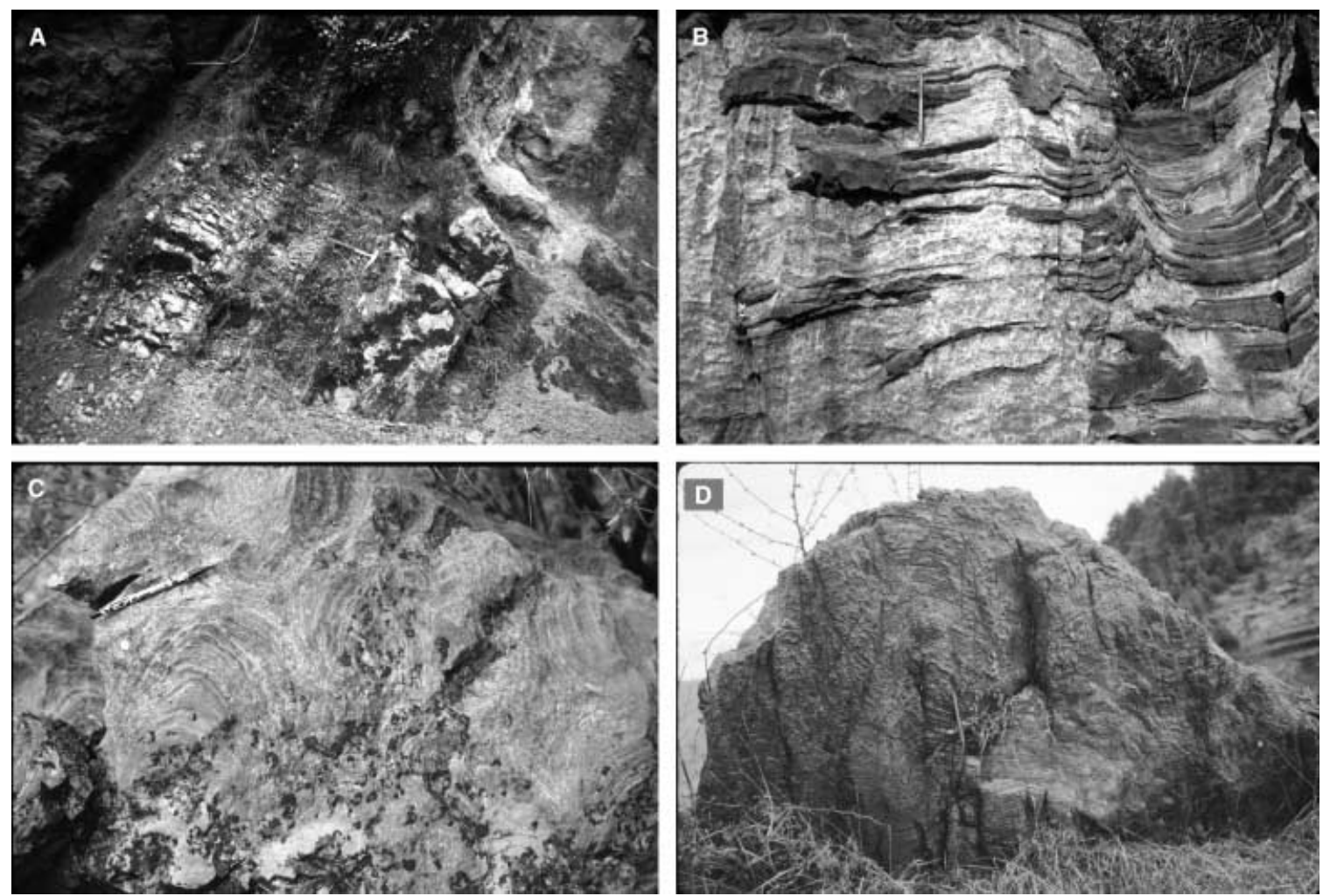

Fig. 12. Facies of lagoonal facies association. (A) Lagoonal cycles consist of organic-rich wackestone/packstoneshale in lower part and stromatolitic dolomite in upper part, Krol C above surface 4, Nigalidhar syncline. (B) Columnar stromatolite with narrow columns and high mud content in the troughs between stromatolite heads, Krol C above surface 4, Mussoorie syncline. (C) Near-plan view of elongate heads of columnar stromatolites, Krol C above surface 4, Mussoorie syncline. (D) Large, isolated stromatolite bioherm (1 m high and $1.5 \mathrm{~m}$ wide) with high mud content, Krol C above surface 4, Mussoorie syncline. Scales: A (hammer), $32 \mathrm{~cm}$; B-D (pencil), 14.5 cm.

large domes are laterally linked or form isolated biostromes up to $120 \mathrm{~cm}$ high and $50-200 \mathrm{~cm}$ in diameter (Fig. 12D). These large biostromes grade upwards into smaller columnar stromatolites and fenestral microbial dolomite. Muddy drapes with peloids, ooids and intraclasts are common in the troughs between high-relief stromatolite heads (Fig. 10B).

\section{Interpretation}

These two facies are interpreted to have been deposited in a back-barrier shelf lagoon environment with stromatolite patch reefs inboard of the peritidal carbonate complex (Fig. 6A). The lack of evidence for wave agitation in the organic-rich wackestone/packstone-shale facies suggests deposition in a low-energy environment. Ooids and peloids in this facies may have been transported by storm waves from the distal peritidal complex, proximal subtidal shoals or patch reefs in the lagoon. Abundant mud drapes between stromatolite heads and the higher synoptic relief of stromatolites indicate that stromatolites had enough space to grow in this quiet-water setting (cf. Pelechaty et al., 1996). However, the presence of coarse carbonate particles and the elongation of some stromatolite heads parallel to depositional dip direction suggests that the environment may have become disturbed during storm or tidal events (cf. Pelechaty \& Grotzinger, 1988; Sami \& James, 1994).

\section{Peritidal siliciclastic-carbonate facies association}

The peritidal siliciclastic-carbonate facies association includes four mappable facies: interbedded sandstone and siltstone, cherty/silty dolomitesiltstone, massive sparry dolomite and fenestral microbial dolomite (Tables 1 and 2). The shared features of these facies include (1) abundant evidence for exposure in the form of vugs, dissolution cavities, desiccation cracks and fenestral fabrics; (2) lack of organic-rich carbonate and shale; (3) randomly distributed, small-scale stromatolites; (4) abundant beds of siltstone and 
very fine- to fine-grained sandstone; and (5) rare ooids, peloids and intraclasts.

The interbedded sandstone and siltstone facies is present in the middle part of the Infra Krol Formation below surface 2 (Fig. 4). Sandstone layers are generally $3-20 \mathrm{~cm}$ thick, very fine to fine grained and well sorted. Medium-grained quartz sandstone layers $20-30 \mathrm{~cm}$ thick are present locally. Ripple cross-lamination is abundant, and minor erosional surfaces are present. Relatively thicker sandstone layers contain shaly flasers and mud drapes (Fig. 7A). Siltstone-rich intervals are commonly $5-30 \mathrm{~cm}$ thick and contain lenticular, 1 to $3 \mathrm{~cm}$ thick, fine-grained sandstone beds. Siltstone layers are characterized by millimetre-thick colour banding that was considered by Singh (1980a) to represent tidal rhythmites. Desiccation cracks, reported from the Solan area by Bhargava \& Singh (1981), were not observed in this study.

The cherty/silty dolomite-siltstone facies is one of the most common facies in the Krol Group (Fig. 4). It consists of $0 \cdot 5$ to $4 \mathrm{~m}$ thick beds of grey to red siltstone and cherty/silty dolomite (Fig. 13A). Silty/cherty dolomite forms $0 \cdot 1$ to $3 \mathrm{~m}$ thick beds of massive, partially or uniformly chertified or silicified dolomicrite and microbial laminae. Chert nodules are concentrated along the bedding planes, but rarely form a continuous bed. Thin sections of the dolomite show $5-15 \%$ well-sorted quartz-muscovite silt and sand grains. Centimetre-sized domal to columnar stromatolites, abundant vugs, fenestral fabrics and locally developed breccias are found in the dolomite. Siltstone layers are 0.5-2 m thick and contain small-scale cross-lamination and ripple marks (Fig. 13B). Gypsum casts and desiccation cracks (Fig. 13C) exist in both siltstone and dolomite beds.

The massive sparry dolomite facies is present as thick units in the upper Krol C below surface 5 near Solan and in the upper Krol D below surface 7 throughout the Lesser Himalaya (Fig. 4). Relatively thin units are also present in the lower Krol $\mathrm{C}$ below surface 4 . The rocks are recrystallized and locally brecciated. Less recrystallized intervals show centimetre-scale domal stromatolites, abundant vugs, fenestral fabric, vadose cements and pisolites, dissolution cavities (Fig. 13D), zebra structure (Fig. 13E) and desiccation cracks (Fig. 13F). The sparry dolomite contains up to $10 \%$ well-sorted quartz silt and sand grains.

The fenestral microbial dolomite facies is characterized by relatively thick dolomite layers with abundant low-relief domal and columnar stro- matolites and unevenly distributed, spar-filled fenestrae and vugs, small dissolution cavities and chert lenses. Tepees and desiccation cracks are common.

\section{Interpretation}

The interbedded sandstone and siltstone facies is interpreted to have accumulated in a shallow subtidal to intertidal siliciclastic ramp environment (Fig. 6B). Siltstone/shale layers and lenses were deposited from suspension in a low-energy setting, possibly in a tidal flat or lagoon. A more energetic environment is inferred for the crosslaminated sandstone layers, which may represent the deposits of tidal subaqueous dunes or bars. This interpretation is supported by the overall stratigraphic position of the facies in the succession (Fig. 7A). The upward transition from laminated calcareous shale and siltstone to abundant cross-laminated, well-sorted sandstone indicates environments of increasing energy. However, in the absence of three-dimensional data, it is not clear whether this facies is related to a delta front, as inferred by Bhattacharya \& Niyogi (1971). It is also not clear to what extent the environment may have been tidally influenced because tidal rhythmites and channel-form sandstone bodies, which are characteristic of many tidal deposits (Nio \& Yang, 1991), have not been observed. Rupke (1974) interpreted this facies as turbidites, but none of the characteristic sedimentary structures of turbidites have been found. In contrast, wellsorted, cross-laminated sandstone, flaser and lenticular bedding and locally developed desiccation cracks (Bhargava \& Singh, 1981) suggest a shallow-water environment of deposition for this facies.

The cherty/silty dolomite-siltstone, massive sparry dolomite and fenestral microbial dolomite facies are interpreted to have been deposited in intertidal to supratidal environments of both ramp and rimmed shelves (Fig. 6). The presence of fenestral fabrics, gypsum casts, vugs, dissolution cavities, vadose cements, pisolites and desiccation cracks indicates that these facies were formed in environments that were occasionally exposed above sea level (cf. Pratt et al., 1992). Low-relief stromatolites, parallel microbial laminae and the lack of significant coarse carbonate particles (ooids, peloids and intraclasts) suggest low-energy, shallow-water conditions where stromatolites might not have had enough space to grow. Additionally, microbial binding and cementation of the sea floor may have prevented the formation of particles, similar to the 

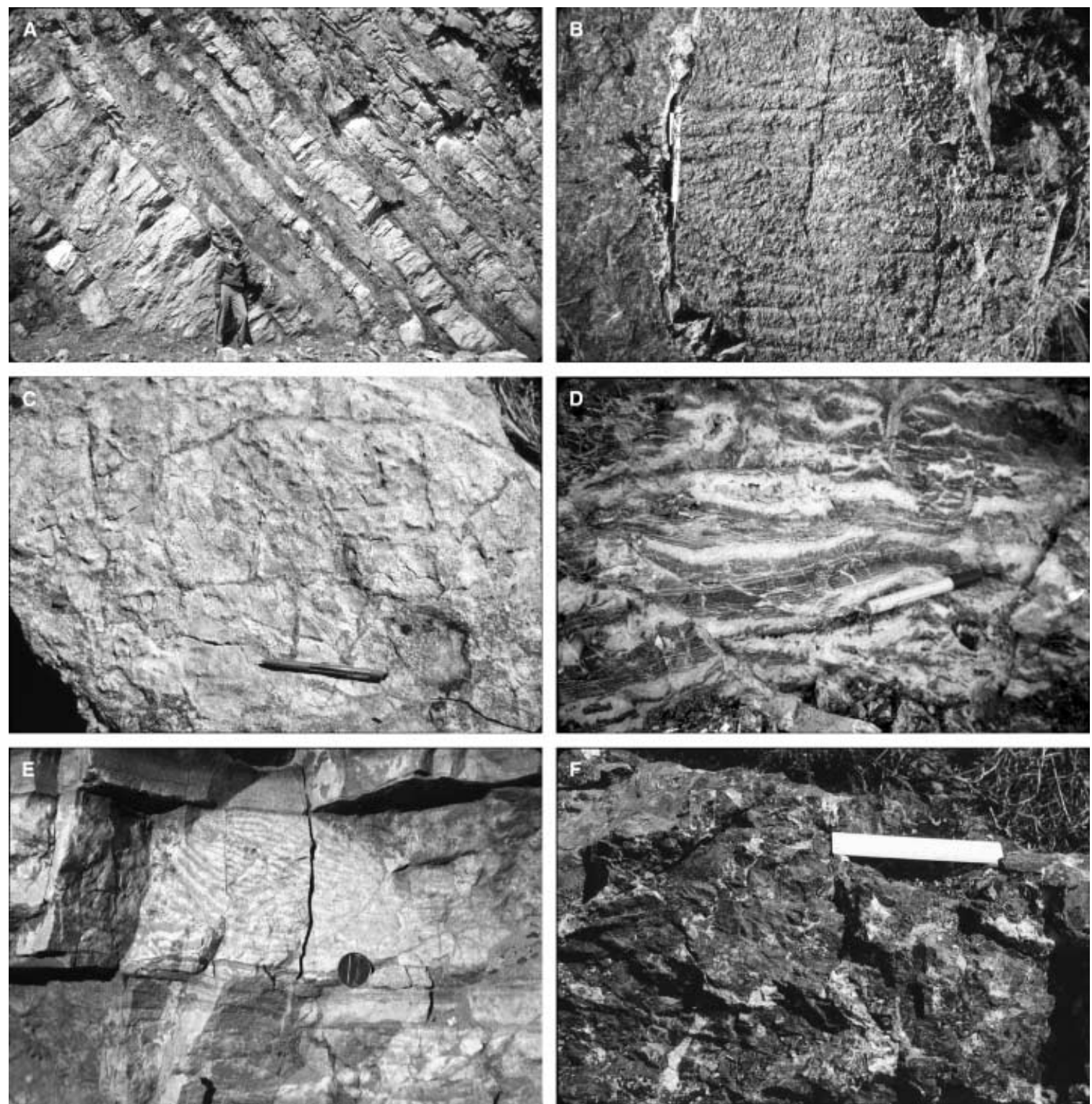

Fig. 13. Facies of peritidal carbonate-siliciclastic facies association. (A) Siltstone-cherty/silty dolomite alternations, Krol D above surface 6, Nainital syncline. (B) Plan view of ripple marks in silty dolomite, Krol D above surface 6, Nainital syncline. (C) Plan view of desiccation cracks in silty dolomite, Krol D above surface 6, Mussoorie syncline. (D) Dissolution cavities in massive sparry dolomite. Krol D above surface 7, Mussoorie syncline. (E) Zebra structure in the massive sparry dolomite, Krol C below surface 4, Nigalidhar syncline. (F) Desiccation cracks in fenestral microbial dolomite, Krol C below surface 4, Dubra, south limb of Mussoorie syncline. Scales: A (field assistant), $1.7 \mathrm{~m}$ high; B and C (pencil), 14.5 cm; D (pen), $12 \mathrm{~cm}$; E (coin), $1.8 \mathrm{~cm}$ in diameter; and F (metre), $15 \mathrm{~cm}$.

widespread sea-floor algal mats of the Bahamas (Bathhurst, 1975; Hardie \& Shinn, 1986). The cherty/silty dolomite-siltstone facies may represent a mixed siliciclastic-carbonate tidal flat (cf. Klein, 1971; Beukes, 1987), with a siliciclastic source on the south-eastern side of the study area, as indicated by the increase in siliciclastic facies in that direction (Fig. 4). It is not known to what extent this non-carbonate sediment was introduced by rivers or by wind. Given the lack of land plants in the Precambrian, it is possible that siliciclastic silt and sand were transported to the carbonate tidal flats by wind and reworked by tidal action, particularly given the well-sorted quartz and muscovite silt and sand grains contained in the dolomite layers. Wind-blown siliciclastic particles are known to have travelled hundreds to thousands of kilometres from their source areas to marine carbonate environments in the modern Persian Gulf (Shinn, 1986) and in 
many ancient deposits (e.g. Dalrymple et al., 1985; Fisher \& Sarnthein, 1988; Osleger \& Montañez, 1996). Zebra structure is a diagenetic feature (Nielsen et al., 1998) commonly associated with peritidal evaporitic sediment or sulphides (Tompkins et al., 1994; Wallace et al., 1994). Its presence in the massive sparry dolomite facies may indicate a saline or evaporitic depositional environment.

\section{Incised valley fills}

Incised valley fills are locally present at two stratigraphic levels in the Infra Krol-Krol succession: above surface 2 within the Infra Krol Formation in the Solan and Nainital areas, and above surface 4 within the Krol C in the Nainital area (Fig. 4).

Siliciclastic deposits above surface 2 in the vicinity of Solan and Nainital are composed of stacked 5 to $25 \mathrm{~m}$ thick, upward-fining cycles. Cycles contain coarse-grained pebbly sandstone at the base, which is overlain by coarse- to medium-grained sandstone, then by medium- to fine-grained sandstone and, finally, by mudstone-siltstone (Fig. 14A and B). Although it is not possible to trace the basal contact of these deposits continuously, measured sections suggest several metres to tens of metres of erosional relief. The sandstone is composed of well-rounded and well-sorted quartz grains, and contains abundant trough, tabular/planar cross-stratification, upper plane bed-parallel lamination and ripple crosslamination.

The sandstone unit above surface 4 at Nainital syncline (Fig. 4) is composed of an upward-fining succession of greenish grey to greyish red, medium- to fine-grained, quartz sandstone and siltstone, with dispersed carbonate clasts near the base (Fig. 14C). Trough and tabular cross-stratification and ripple cross-lamination are present but not common. In the cliff east of Sariatal, interbedded siltstone and sandstone onlaps the underlying karstic breccia with a $10-15^{\circ}$ difference in the angle of dip.

\section{Interpretation}

The sandstone unit above surface 2 at Solan has been variously interpreted as aeolian (Auden, 1934), shallow marine (Bhattacharyya \& Chanda, 1971), neritic/littoral (Bhattacharya \& Niyogi, 1971) and intertidal to subtidal sand bars (Bhargava \& Singh, 1981). We tentatively interpret an incised valley setting on the basis of (1) conglomerate and sandstone units that are thicker than those that might be ascribed to the filling of fluvial or tidal channels; (2) abundant crossbedding in the sandstone; (3) upward-fining cycles; (4) lateral thickness variations revealed by measuring multiple sections; and (5) a sharp, erosional basal contact against siltstone/shale (cf. Zaitlin et al., 1994; MacDonald et al., 1998). The sandstone unit above surface 4 at Nainital is interpreted as a karst valley or incised valley fill owing to the presence of karstic breccia below the sand unit. The textural and compositional maturity of sandstones in both examples is consistent with deposition at least in part during marine transgression (cf. Dalrymple et al., 1992; Zaitlin et al., 1994).

\section{Karstic facies association}

The karstic facies association includes two lithofacies: karstic breccia and calcrete (Tables 1 and 2). These two facies are intimately related to the two surfaces (surface 4 and 5) that are interpreted as karstic unconformities (Fig. 4; Jiang et al., 2002). The karstic breccias are of two kinds, polymict and monomict. Polymict breccias overlie karstic unconformities as irregular sheets or smaller patches in topographic lows. They are typically composed of a mixture of sharp-edged carbonate fragments and chert rubble, together with less common blocks of pedogenic pisolite (palaeosol), claystone and green shale. Interstices between blocks are filled by siltstone, sandy dolomite or dolomitic sandstone; these rock types are strongly silicified in places. Monomict breccias are generally associated with small caves and dykes below a karstic unconformity. They are characterized by relatively homogeneous clast composition, consistent with that of associated in situ stratigraphy. Interstices in these breccias are filled by sandy dolomite, siltstone or claystone. Polymict and monomict breccias are interstratified in large karstic depressions along surface 4 , but the contacts between them are vague or gradational, and their thicknesses vary laterally.

The calcrete facies is associated with karstic breccias at surface 5 . It is expressed as thin lenses or layers overlying brecciated cherty dolomite and as lenses filling small karst depressions. Calcrete profiles are characterized by reddish, yellowish or buff-coloured, massive siltstone or fine- to very fine-grained sandstone displaying (1) micritic carbonate (dolomudstone and lime mudstone) nodules or lenses; (2) pedogenic pisolite/ooid lenses showing reverse 

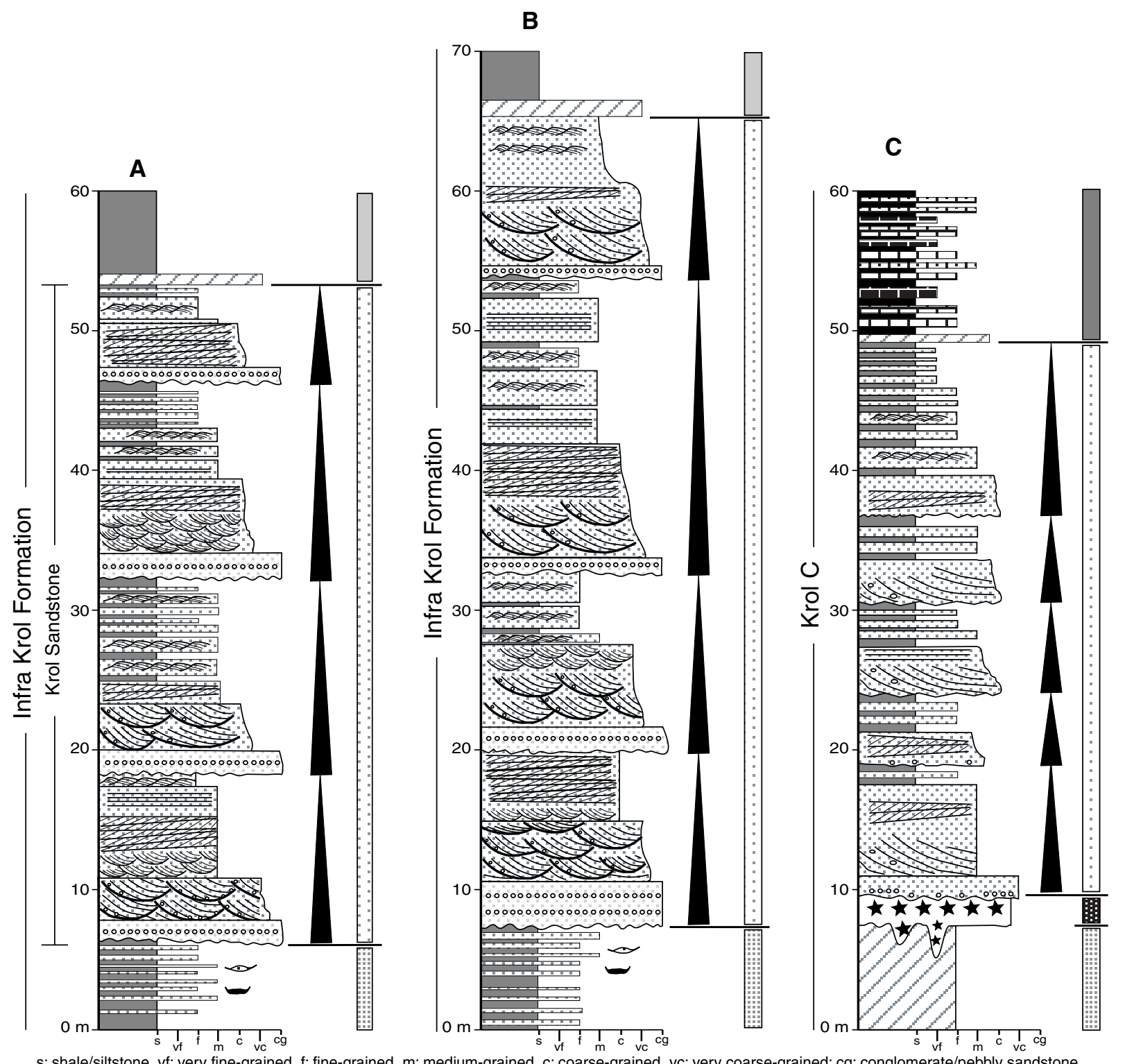

$\mathrm{s}:$ shale/siltstone, vf: very fine-grained, f: fine-grained, $\mathrm{m}$ : medium-grained, c: coarse-grained, vc: very coarse-grained; cg: conglomerate/pebbly sandstone

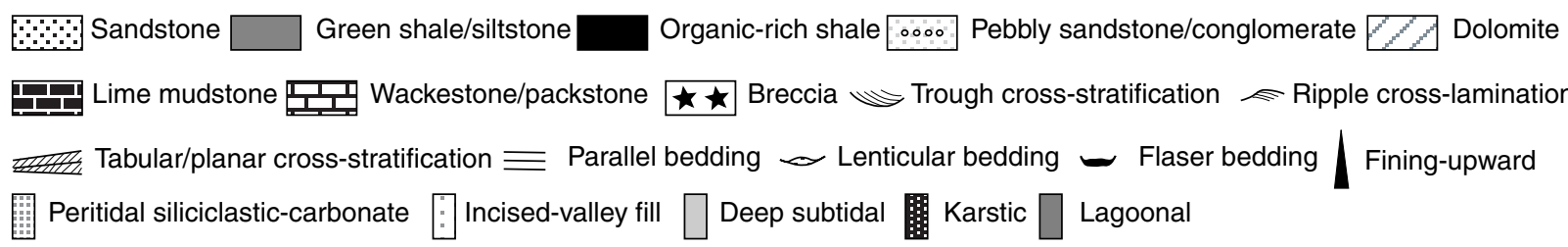

Fig. 14. Representative sections of incised valley fill. (A) At surface 2 near Solan, south limb of Krol syncline, north of Basal village. (B) At surface 2 at Nainital syncline, south-east of Nainital lake. (C) At surface 4, Nainital syncline, north of Runsi village.

grading; and (3) associated breccias, chert and iron oxide nodules.

\section{Interpretation}

The karstic facies association is interpreted to relate to karstic landforms, including karstic depressions, caves, dykes and pockets along a karst surface. Polymict karstic breccias are generally considered as mantling breccias (Choquette \& James, 1988; Kerans \& Donaldson, 1988), and monomict karstic breccias are commonly interpreted as forming due to the collapse of cave ceilings (Choquette \& James, 1988; Kahle, 1988). Interstratification of these breccias in large karstic 
depressions (Jiang et al., 2002) may have resulted from multiple stages of collapse, with mantling breccias being transported through a cave or karst valley system between episodes of collapse. The breccias are thought to be palaeokarstic and not related to modern karstification. They are stratigraphically restricted, extensive but discontinuous. They fill fissures and are overlain with sharp contact by younger stratigraphic units. Solution features such as pipes that might connect the breccias with younger or modern karst are absent in the immediately overlying beds (cf. Wright, 1982). Breccia fragments are reworked into overlying ooid grainstone/packstone and, at Nainital, into sandstone.

The calcrete facies is interpreted to represent palaeosol along an exposure surface. Associated features are similar to those widely documented in palaeosol profiles (e.g. Mustard \& Donaldson, 1990; Pelechaty \& James, 1991; Wright, 1994).

\section{CYCLES AND CONTROLS}

\section{Metre-scale cycles}

Two types of metre-scale cycles are present in the Krol Group: stromatolitic cycles and shale-based cycles. Stromatolitic cycles are commonly bounded by minor erosional surfaces, and the most complete examples contain, from base to top: (1) oncoid-intraclast-ooid dolograinstone; (2) wavy microbial laminae with intraclasts, ooids, peloids and oncoids; (3) domal stromatolites with upward-increasing synoptic relief; (4) columnar stromatolites; (5) parallel microbial laminae; and (6) fenestral microbial laminae (Fig. 10A and B). However, the abundance of the above component facies varies from one cycle to another. Shalebased cycles are composed of fine-grained siliciclastic lower parts and carbonate-dominated upper parts. These cycles are interpreted to shoal upwards on the basis of upsection increases in small-scale cross-lamination and minor erosional surfaces (Fig. 7B and C) or increases in grainsupported textures and stromatolitic/microbial dolomite (Fig. 10B and C).

Stromatolitic cycles are present within the peritidal carbonate complex and lagoonal facies associations. These cycles record a progression from shallow subtidal to supratidal environments. Efforts to trace cycles in the available outcrop at Solan and at Nigalidhar syncline showed that they are extremely variable: the cycle boundaries disappear and component facies pinch out or interfinger with other facies in $<1 \mathrm{~km}$ (Fig. 15). The poor traceability of these cycles suggests an autogenic origin, in contrast to the metre-scale peritidal cycles of the Palaeoproterozoic Rocknest platform (Grotzinger, 1986b) and of the Neoproterozoic Chuar Group in the Grand Canyon (Dehler et al., 2001), which can be traced over tens to hundreds of kilometres and are interpreted to relate to sea-level fluctuations. Among several models for the development of autogenic cycles in peritidal environments (e.g. Pratt \& James, 1986; Cloyd \& Demicco, 1990; Sami \& James, 1994), the aggrading tidal flat-island model of Sami \& James (1994), modified from Pratt \& James

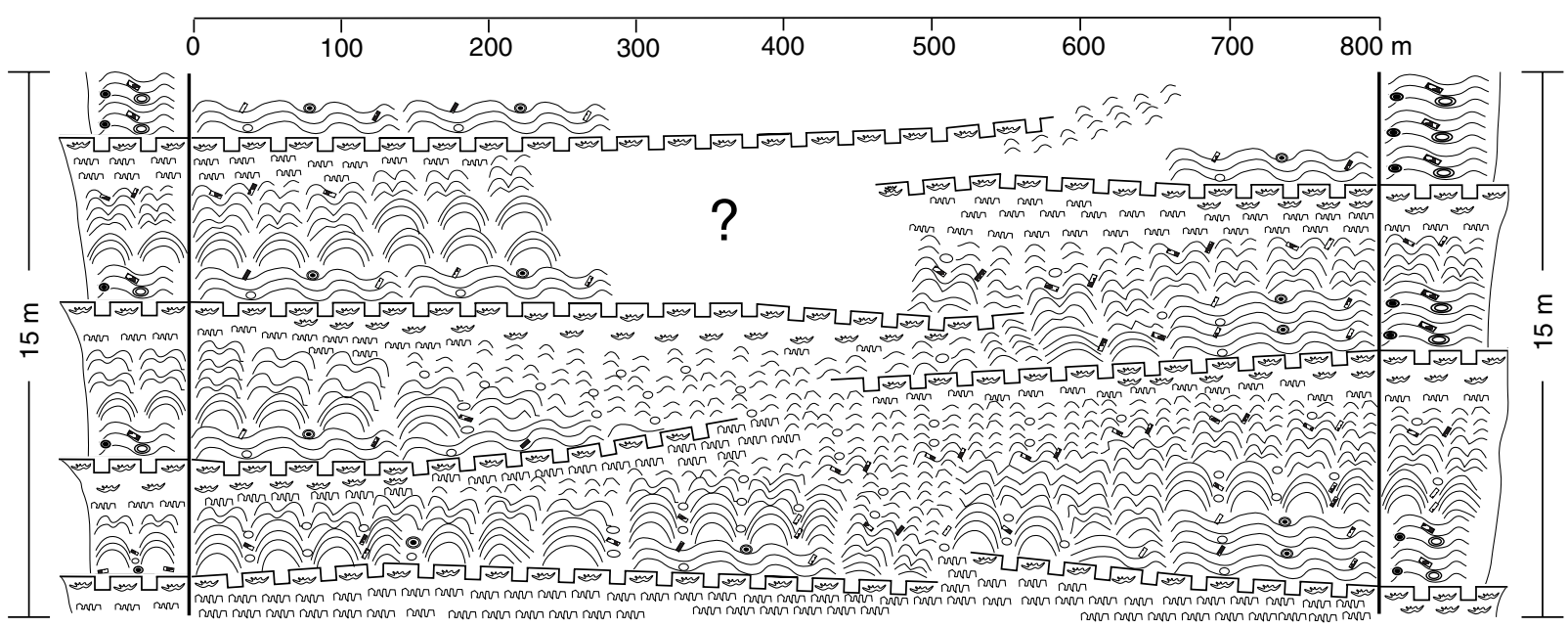

Fig. 15. Tracing of cycle boundaries and component facies of stromatolitic cycles along a well-exposed cliff near Solan. The stratigraphic interval is located between surfaces 4 and 5 .

(c) 2003 International Association of Sedimentologists, Sedimentology, 50, 921-952 
(1986), seems to provide a better interpretation for the development of stromatolitic cycles in the Krol Group: (1) overall carbonate production and accumulation in the peritidal complex was sufficient to track sea level so that these environments remained shallow; (2) sediment accumulated preferentially in locally developed shallow subtidal environments, and least abundantly in supratidal environments; (3) because of lateral variations in the rate of carbonate production and accumulation, subtidal environments were able to aggrade locally into the supratidal zone, forming upward-shallowing cycles, and previously supratidal settings were able to evolve into subtidal ones; (4) repetition of these trends resulted in a mosaic of locally developed cycles. Although sea-level change is not required to account for observed features (Fig. 15) in the above model, subsidence is needed to create accommodation. These ideas are testable against other field examples and through computer modelling beyond the scope of this paper.

Shale-based cycles are traced with difficulty in available outcrop, but different numbers of cycles are observed in closely spaced sections. In the shelf lagoon deposits (Fig. 10B and C), cycles of this type may represent the migration of stromatolite patch reefs or local sand bars.

\section{Siltstone-silty/cherty dolomite alternations}

Siltstone-silty/cherty dolomite alternations are composed of interbedded siltstone and dolomite, but do not display an unequivocal upward-shallowing trend and, because a systematic pattern of this sort is absent, we avoid the word cycle for these deposits. The thickness of siltstone and silty/cherty dolomite layers varies. In some cases, 0.5 to $2 \mathrm{~m}$ thick, pure siltstone and 0.5 to $3 \mathrm{~m}$ thick silty/cherty dolomite constitute simple siltstone-carbonate alternations. In other cases, the siltstone-rich intervals contain one to three layers of 0.1 to $0.4 \mathrm{~m}$ thick silty/cherty dolomite. Subaerial exposure features such as desiccation cracks were found in both siltstone and dolomite. In the peritidal carbonate deposits, an episodic increase followed by decrease in siliciclastic flux caused by climatic changes may have been responsible for developing these siltstone-carbonate alternations. Variations in sediment influx of climatic origin are not necessarily in phase with glacial-eustatic fluctuations, and are highly dependent on palaeogeographic location (Perlmutter et al., 1998).

\section{Non-cyclic intervals}

Non-cyclic intervals are present throughout the Infra Krol Formation (with the exception of the upward-fining cycles within incised valley fills at surface 2) and in parts of the Krol Group (Fig. 5). They are expressed as a monotonous lithology such as shale, thick oolitic grainstone or massive dolomite, or as interbedded siliciclastic-carbonate rocks lacking predictable thickness or facies stacking patterns. The thick green/grey shale of the Infra Krol Formation, interbedded shalelimestone of lower Krol A and organic-rich wackestone-shale above surface 4 and 5 in Garhwal syncline (Fig. 5) are interpreted as having been deposited in a subtidal shelf or deep lagoon that was too deep to record significant changes in environment and facies. Intervals of more interest are those with shallow-water indicators. Grotzinger (1986b) and Elrick (1995) suggested that the apparent 'non-cyclic' interbedding of facies of similar water depth results from incomplete shoaling during each 'cycle' owing to the effects of long-term net increase in sea level that masks the effects of short-term sea-level oscillations. This interpretation requires rapid long-term sealevel rise, and the non-cyclic intervals should be present universally in the transgressive parts of sequences. This expectation, however, is not borne out in the Krol Group. With the exception of thick oolitic grainstone observed above surface 4 , and interpreted to have accumulated during transgression, non-cyclic intervals tend to underlie karstic unconformities or other regional stratigraphic discontinuities (Fig. 5). The absence of cycles implies that short-term sea-level changes, if they occurred, were minimal, and abundant shallow-water features indicate deposition in a sustained intertidal to supratidal environment not subject to the episodic introduction of siliciclastic sediment. Given the lack of precise age control, the time required for the accumulation of non-cyclic carbonates cannot be estimated, and the origin of the implied environmental stasis is accordingly difficult to interpret. A possible interpretation is that, during the deposition of these non-cyclic intervals, the platform was relatively flat, and wide facies belts of more or less the same water depth and hydrodynamic condition developed. If the width of facies belts was large compared with the lateral distance over which facies boundaries shifted during a particular interval of time, relatively invariant facies successions would result. 


\section{Cycle stacking patterns}

It is widely appreciated that metre-scale cycles show systematic changes in cycle types, lithofacies and thickness vertically through carbonate successions, reflecting changes in accommodation that may be related in some cases to different orders of eustatic oscillation (e.g. Goldhammer et al., 1990, 1993; Osleger \& Read, 1991; Montañez \& Read, 1992; Montañez \& Osleger, 1993; Elrick, 1995). Upward-shallowing trends thicker than metre-scale cycles do exist in the Krol Group (Fig. 16; see also Figs 4 and 5). However, these trends cannot be correlated across the platform and, more importantly, they become vague or disappear on the proximal side of the platform (Mussoorie to Nainital synclines). The number of metre-scale cycles within each upward-shallowing trend varies according to palaeogeographic location (Fig. 16). Although eustatic change is a possible cause of observed cycle stacking patterns, differential subsidence of the passive margin may have been responsible for lateral variations in the number of cycle sets within a particular interval. Regardless of the origin of metre-scale cycles and larger scale upward-shallowing trends, the reliability of cycle hierarchy for stratigraphic correlation in the Krol seems to be limited, given the fact that both metre-scale cycles and their stacking patterns may vary according to the palaeogeographic location.

\section{PLATFORM DEVELOPMENT}

Four platform geometries are suggested for the Infra Krol-Krol interval: (1) siliciclastic ramp; (2) carbonate ramp; (3) peritidal rimmed shelf; and (4) open shelf. Because no slope/basinal facies crop out in the Lesser Himalaya, the differentiation of ramp and open shelf is tentative.

\section{Siliciclastic ramp}

The Infra Krol Formation is thought to have accumulated at a siliciclastic ramp that developed atop the glacial-marine diamictites of the Blaini Formation (Fig. 17A). The abrupt lithological transition is consistent with rapid sea-level rise and sediment starvation during deglaciation, and a palaeoenvironment mostly below fairweather wave base. Facies were stacked aggradationally for most of the time, with representative lithologies of thinly laminated calcareous shale and siltstone. In the late stages, progradation resulted in the deposition of siltstone and fine-grained sandstone (Figs 7A and $17 \mathrm{~B})$.

\section{Carbonate ramp}

The carbonate ramp represented by the upper part of Krol A to lower Krol C inherited the geometry of the siliciclastic ramp. Initiation of carbonate production may have been related to reduced siliciclastic influx, either climatically induced or resulting from lowering of the topography in the hinterland of the platform. The deep subtidal ramp (Fig. 17C) is represented by shale-limestone rhythmites, and the peritidal ramp (Fig. 17D) by interbedded siltstone and dolomite (Krol B) and massive dolomite (lower Krol C). Lateral facies variation is limited, consistent with the absence of reefs, shoals or other palaeogeographic complexity.

\section{Peritidal rimmed shelf}

Basal deposits of the peritidal rimmed shelf accumulated above the pre-existing low-gradient ramp (Fig. 17D). The rimmed shelf was characterized by a persistent accretionary reefal rim (inferred) and a peritidal, stromatolite-rich carbonate complex over a widespread sand shoal (Fig. 17E). Increased carbonate production and accumulation in the complex led to the development of a deepening and increasingly restricted shelf lagoon. Expansion of the complex into the shelf lagoon was localized, possibly because of nutrient limitation (cf. Schlager, 1981). Locally developed sand shoals or bars and stromatolite patch reefs formed bathymetric highs in the lagoon. Siliciclastic influx from the south-eastern side of the shelf eventually led to progradation of the peritidal complex, and shut down the carbonate factory, leading in turn to the drowning of the platform (Fig. 17F).

\section{Open shelf}

The interval from surface 6 to surface 8 is tentatively interpreted to represent an open shelf (or distally steepened ramp of Read, 1985), given that the platform evolved from a rimmed shelf. The shelf rim and peritidal complex were not able to be re-established after the flooding event, possibly because of the increased siliciclastic pollution (Fig. 17G and H). 


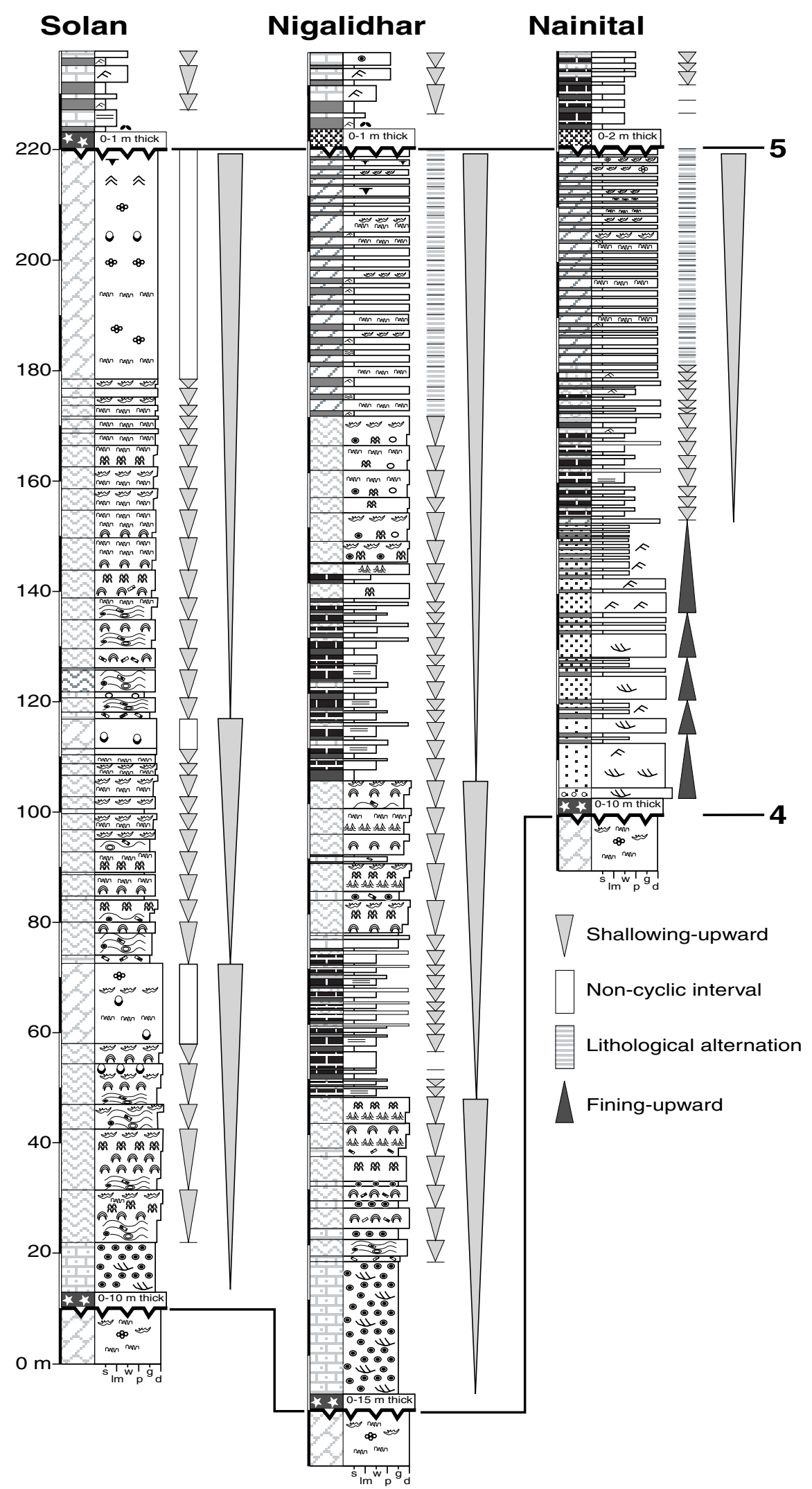

Fig. 16. Example of cycles and their stacking patterns for the interval between surfaces 4 and 5 . 


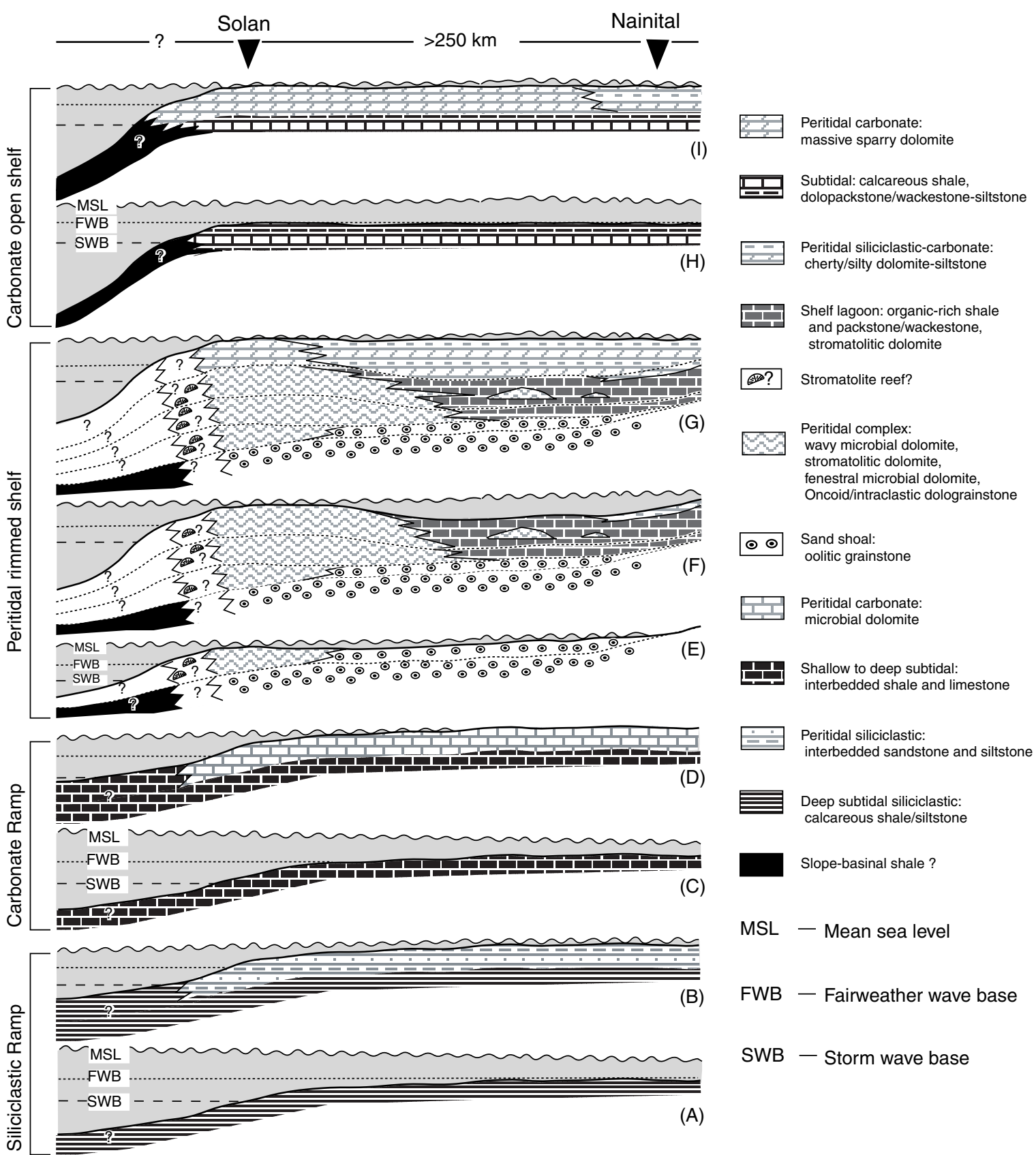

Fig. 17. Summary of platform evolution. (A and B) Siliciclastic ramp (Infra Krol Formation to lower Krol A). (C and D) Carbonate ramp (upper Krol A to lower Krol C). (E-G) Peritidal rimmed shelf (middle Krol C to Krol D). (H and I) Open shelf (upper Krol D to Krol E). See text for interpretation.

\section{Termination of the Krol platform}

During the final phase of evolution, the Krol platform was drowned and buried by deep-water, phosphorite-bearing shale and bedded chert of the basal Tal Group and, in turn, by up to $2500 \mathrm{~m}$ of shallow-marine to fluvial siliciclastic deposits (Singh \& Rai, 1983).

\section{NEOPROTEROZOIC PASSIVE MARGIN OF NORTHERN INDIA}

The Neoproterozoic strata of the Lesser Himalaya have been interpreted as deposits of an isolated basin centred in Mussoorie syncline, with its western margin in the Krol Hills and eastern margin in the vicinity of Nainital (e.g. Shanker 


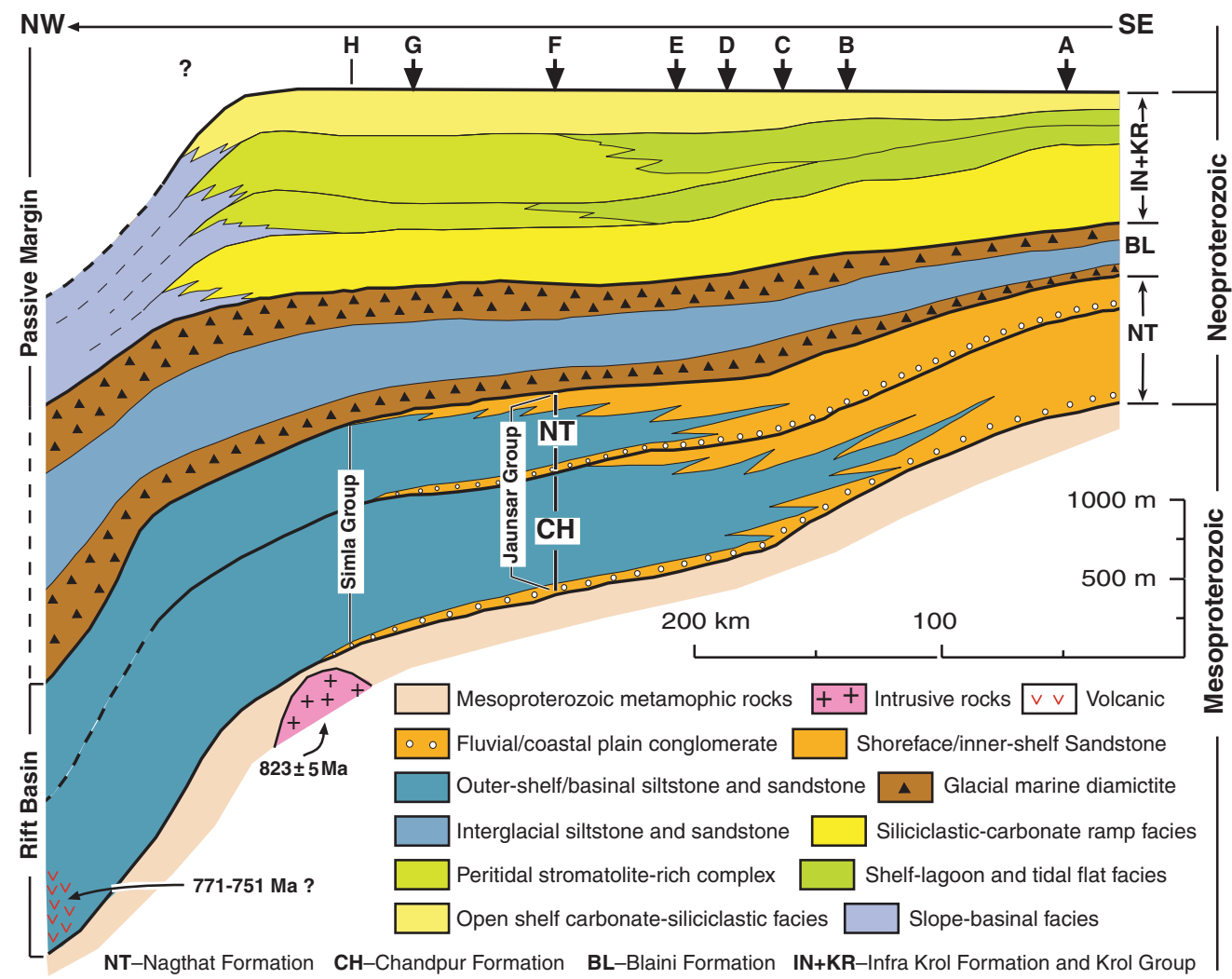

Fig. 18. Neoproterozoic stratigraphy and basin evolution of the Lesser Himalaya, northern India. Measured sections (A-G) located in Fig. 1. Stratigraphy of section H (Simla) is summarized from Valdiya (1970) and Kumar \& Brookfield (1987). The geology north-west of Simla (question mark) is inferred from our stratigraphic analysis. U-Pb age of 823 × 5 Ma intrusive rocks from Singh et al. (2002) and 771-751 Ma age of Malani igneous rocks from Torsvik et al. (2001).

et al., 1989; Virdi, 1991; Shanker \& Mathur, 1992), or an isolated basin with its northern margin in the present-day High Himalaya and its southern margin connecting with the Vindhyan basin (e.g. Bhattacharya, 1982; Saxena, 1981). In contrast, Brookfield (1993) suggested that the stratigraphic record represents the inner part of a north-facing passive continental margin. The main evidence offered in support of the isolated basin interpretation is that (1) the thickness of the Krol and Tal groups attains a maximum in Mussoorie syncline; and (2) similar lithofacies are not present in the High Himalaya. However, our stratigraphic studies indicate that the reported thickness variation of the Krol Group is influenced by a combination of incomplete exposure and tectonic repetition (Jiang et al., 2002). Facies analysis of the Infra Krol Formation and Krol Group reported here reveals a platform architecture that is more consistent with the existence of a north- to north-west-facing passive margin.

The Neoproterozoic rift to passive margin succession in the Lesser Himalaya is summarized in
Fig. 18. The basal part of the succession is represented by the Jaunsar Group in the south-easternmost synclines and by the Simla Group in the north-west. These units unconformably overlie the Mesoproterozoic metamorphic rocks assigned to the Berinag Quartzite in the south-east and Shali Group near Simla, where intrusive rocks dated as $823 \pm 5$ Ma have been reported (Singh et al., 2002). Facies analysis reveals an overall fining towards the north-west, from fluvial- and coastal plain-dominated sandstone and conglomerate (Nagthat Formation) at Nainital syncline to shoreface- and inner-shelf siltstone and sandstone (Chandpur and Nagthat formations) in Garhwal to Nigalidhar synclines (Ghosh, 1991) and to muddy delta-front and outer-shelf shale/siltstone and sandstone (Simla Group) at Simla (Kumar \& Brookfield, 1987). Turbidites have been reported within the latter (Valdiya, 1970). An erosional unconformity has been documented at or near the Chandpur/Nagthat contact (Pant \& Shukla, 1999). Rift-related mafic volcanic rocks and tuff/tuffaceous sandstone are present in north-western 
areas, and $\mathrm{U}-\mathrm{Pb}$ ages of $771 \pm 2$ and $751 \pm 3 \mathrm{Ma}$ have been reported (Torsvik et al., 2001). Unconformably overlying the Jaunsar and Simla groups are diamictite, siltstone and sandstone of inferred glacial and glacial-marine origin (Blaini Formation). This unit has three lithologically distinguishable parts: a lower diamictite-rich part comprising three to four massive diamictite intervals separated by siltstone/mudstone; a middle siltstone and sandstone part with occasional lenses or thin layers of ferruginous shale; and an upper diamictite with an erosional unconformity at its base. Although the Blaini Formation is not directly dated, the two diamictite-rich intervals may represent records of the two most widespread Neoproterozoic glaciations: the Sturtian and Marinoan or Varanger events.

The stratigraphic location of the rift to passivemargin transition is uncertain, but is tentatively interpreted within or perhaps at the base of the glacigenic units (Fig. 18). A passive margin setting for the post-glacial carbonate strata described in this paper is inferred on the basis of scale, the absence of igneous rocks and comparatively simple facies and thickness trends, with no evidence for substantial syndepositional tectonism comparable to that of foreland basins (cf. Plint et al., 1993).

In the High Himalaya, a Neoproterozoic succession comparable to that of the Lesser Himalaya has not been documented, and the absence of such a succession has been used to support the argument that the basin now exposed in the Lesser Himalaya was isolated. However, the apparent absence of equivalent units in the High Himalaya is mainly a statement about lithic mismatch of poorly dated rocks. It is predicted here that, if correlative rocks are present in the High Himalaya, they should be composed of finegrained siliciclastic and carbonate slope and basinal deposits very different from the platformal carbonate rocks of the Lesser Himalaya (Fig. 18).

Overlying the carbonate deposits of the Krol platform of the Lesser Himalaya are lower Cambrian siliciclastic rocks (Tal Group), which are unconformably overlain in turn by Permian strata. In the High Himalaya, however, middle Cambrian to Carboniferous rocks have been recognized, as well as the evidence for early Ordovician deformation and granite intrusion (e.g. Brookfield, 1993). One interpretation is that, after the early Cambrian, the Lesser Himalaya was uplifted, shifting the depocentre towards the north. This may have been related to the collision between India and East Antarctic between $\approx 550$ to $\approx 525$ Ma (e.g. Torsvik et al., 2001).

\section{SUMMARY}

Detailed studies of facies and facies associations reveal that the terminal Proterozoic Infra KrolKrol succession of northern India represents a north- to north-west-facing carbonate platform, an interpretation that departs markedly from existing depositional models for these rocks. The platform evolved from a siliciclastic ramp, to carbonate ramp, to peritidal rimmed shelf to open shelf. The peritidal carbonate complex of the rimmed shelf is analogous to platform margin reefs of the Phanerozoic, separating and restricting a shelf lagoon from the open ocean.

Stromatolitic cycles, shale-based cycles and siltstone-silty/cherty dolomite alternations are present in the Krol Group. The cycles and apparently 'cyclic' lithic alternations are laterally discontinuous, and are thought to be primarily autogenic. Stromatolitic cycles are interpreted to have formed by facies migration related to variable carbonate production. Shale-based cycles are interpreted to have formed through the migration of locally developed carbonate sand shoals or bars or stromatolite patch reefs. Siltstone-silty/cherty dolomite alternations developed as a result of episodic siliciclastic influx from the proximal side of the shelf lagoon. Eustatic fluctuations are neither required nor precluded for these alternations. Non-cyclic intervals suggest that the dimensions of any particular substrate were large compared with the scale of lateral shifts in facies. Cycle stacking patterns are shown to change across the platform, possibly owing to the differential subsidence of the passive margin.

The overall Neoproterozoic succession of the Lesser Himalaya is interpreted to represent a rift basin to passive margin, with rift to post-rift transition located within or perhaps at the base of the glacial unit (Blaini Formation). Equivalent Neoproterozoic successions in the High Himalaya, if preserved, may be mainly slope/basinal facies represented by fine-grained siliciclastic and carbonate rocks, lithologically different from those of the Lesser Himalaya.

\section{ACKNOWLEDGEMENTS}

We are especially grateful to R. Shanker (Geological Survey of India), I. B. Singh and S. Kumar 
(Lucknow University), V. C. Tewari (Wadia Institute), O. P. Goel and S. B. Misra (Kumun University) for stimulating discussions and for advice about sections suitable for this study. We thank Sidney Hemming and Paul Olsen, journal reviewers Paul Myrow and David Osleger, and Isabel Montañez (editor) for constructive comments that helped to improve the paper significantly. The research was supported by National Science Foundation Grant EAR 96-14070. Lamont-Doherty Earth Observatory Contribution Number 6465.

\section{REFERENCES}

Auden, J.B. (1934) The geology of the Krol belt. Geol. Surv. India Rec., 71, 357-454.

Bathhurst, R.G.C. (1975) Carbonate Sediments and Their Diagenesis. Elsevier, Amsterdam, 658 pp.

Beukes, N.J. (1987) Facies relations, depositional environments and diagenesis in a major Proterozoic stromatolitic carbonate platform to basinal sequence, Campbellrand Supergroup, Transvaal Supergroup, southern Africa. Sed. Geol., 54, 1-46.

Bhargava, O.N. (1979) Lithostratigraphic classification of the Blaini, Infra-Krol, Krol and Tal formations: a review. J. Geol. Soc. India, 20, 7-16.

Bhargava, A.K. and Singh, I.B. (1981) Some paleoenvironmental observations on the Infra Krol Formation, Lesser Himalaya. J. Paleontol. Soc. India, 25, 26-32.

Bhatt, D.K. (1991) The Precambrian-Cambrian transition interval in Himalaya with special reference to small shelly fossils - a review of current status of work. J. Palaeontol. Soc. India, 36, 109-120.

Bhattacharya, A.R. (1982) The Lesser Himalaya sediments: Precambrian span. In: Geology of Vindhyanchal (Eds K.S. Valdiya, S.B. Bhatia and V.K. Gaur), pp. 200-210. Hindustan Publishing Corporation, Delhi, India.

Bhattacharyya, A. and Chanda, S.K. (1971) Petrology and origin of the Krol Sandstone around Solan, Himachal Pradesh. J. Geol. Soc. India, 12, 368-374.

Bhattacharya, S.C. and Niyogi, D. (1971) Geological evolution of the Krol Belt in Simla Hills, H.P. Himalayan Geol., 1, 178-212.

Bosence, D.W.J., Wood, J.L., Rose, E.P.F. and Qing, H. (2000) Low- and high-frequency sea-level changes control peritidal carbonate cycles, facies and dolomitization in the Rock of Gibraltar (Early Jurassic, Iberian Peninsula). J. Geol. Soc. London, 157, 61-74.

Brookfield, M.E. (1993) The Himalayan passive margin from Precambrian to Cretaceous times. Sed. Geol., 84, 1-35.

Burne, R.V. and Moore, L.S. (1987) Microbialites: organosedimentary deposits of benthic microbial communities. Palaios, 2, 241-254.

Choquette, P.W. and James, N.P. (1988) Introduction. In: Paleokarst (Eds J.P. James and P.W. Choquette), pp. 1-21. Springer-Verlag, New York.

Cloyd, K.C. and Demicco, R.V. (1990) Tidal channel, levee, and crevasse-splay deposits from a Cambrian tidal channel system: a new mechanism to produce shallowing-upward sequences. J. Sed. Petrol., 60, 73-83.
Crowell, J.C. (1999) Pre-Mesozoic ice ages: their bearing on understanding the climate system. Geol. Soc. Am. Mem., 192, 45-66.

Dalrymple, R.W., Narbonne, G.M. and Smith, L. (1985) Eolian action and the distribution of Cambrian shales in North America. Geology, 13, 607-610.

Dalrymple, R.W., Zaitlin, B.A. and Boyd, R. (1992) Estuarine facies models: conceptual basis and stratigraphic implications. J. Sed. Petrol., 62, 1130-1146.

Dehler, C.M., Elrick, M., Karlstrom, K.E., Smith, G.A., Grossey, L.J. and Timmons, J.M. (2001) Neoproterozoic Chuar Group ( 800-742 Ma), Grand Canyon: a record of cyclic marine deposition during global cooling and supercontinent rifting. Sed. Geol., 141-142, 465-499.

Elrick, M. (1995) Cyclostratigraphy of Middle Devonian carbonates of the eastern Great Basin. J. Sed. Res., B65, 61-79.

Feldmann, M. and McKenzie, J.A. (1998) Stromatolitethrombolite associations in a modern environment, Lee Stocking Island, Bahamas. Palaios, 13, 201-212.

Fisher, A.G. and Sarnthein, M. (1988) Airborne silts and dune-derived sands in the Permian of the Delaware Basin. J. Sed. Petrol., 58, 637-643.

Ghosh, S.K. (1991) Paleoenvironmental analysis of the Late Proterozoic Nagthat Formation, NW Kumaun Lesser Himalaya, India. Sed. Geol., 71, 33-45.

Goldhammer, R.K., Dunn, P.A. and Hardie, L.A. (1990) Depositional cycles, composite sea level changes, cycle stacking patterns, and the hierarchy of stratigraphic forcing - examples from platform carbonates of the Alpine Triassic. Geol. Soc. Am. Bull., 102, 535-562.

Goldhammer, R.K., Lehmann, P.J. and Dunn, P.A. (1993) The origin of high-frequency platform carbonate cycles and third-order sequences (Lower Ordovician El Paso Gp, west Texas): constraints from outcrop data and stratigraphic modeling. J. Sed. Petrol., 63, 318-359.

Grotzinger, J.P. (1986a) Evolution of Early Proterozoic passivemargin carbonate platform, Rocknest Formation, Wopmay Orogen, Northwest Territories, Canada. J. Sed. Petrol., 56, 831-847.

Grotzinger, J.P. (1986b) Cyclicity and paleoenvironmental dynamics, Rocknest platform, northwest Canada. Geol. Soc. Am. Bull., 97, 1208-1231.

Grotzinger, J.P. (1989a) Construction of early Proterozoic (1.9 GA) barrier reef complex, Rocknest Platform, Northwest Territories. In: Reefs - Canada and Adjacent Areas (Eds H. Geldsetzer, N.P. James and G. Tebbut), Can. Soc. Petrol. Geol. Mem., 13, 30-37.

Grotzinger, J.P. (1989b) Facies and evolution of Precambrian depositional systems: emergence of the modern platform archetype. In: Controls on Carbonate Platform and Basin Development (Eds P.D. Crevello, J.L. Wilson, J.F. Sarg and J.F. Read), SEPM Spec. Publ., 44, 79-106.

Grotzinger, J.P. and James, N.P. (2000) Precambrian carbonates: evolution of understanding. In: Carbonate Sedimentation and Diagenesis in the Evolving Precambrian World (Eds J.P. Grotzinger and N.P. James), SEPM Spec. Publ., 67, 3-20.

Hardie, L.A. and Shinn, E.A. (1986) Carbonate depositional environments, Part 3: Tidal flats. Colorado School Mines Q., 81, 1-74.

Hodges, K.V. (2000) Tectonics of the Himalaya and southern Tibet from two perspectives. Geol. Soc. Am. Bull., 112, 324350 .

Hoffman, P.F. (1989) Pethei reef complex (1.9 Ga), Great Slave Lake, N.W.T. In: Reefs - Canada and Adjacent Areas (Eds 
H. Geldsetzer, N.P. James and G. Tebbutt), Can. Soc. Petrol. Geol. Mem., 13, 38-48.

Hoffman, P.F., Kaufman, A.J., Halverson, G.P. and Schrag, D.P. (1998) A Neoproterozoic snowball earth. Science, 281, 1342-1346.

Holland, S.M. and Patzkowsky, M.E. (1998) Sequence stratigraphy and relative sea-level history of the Middle and Upper Ordovician of the Nashville Dome, Tennessee. J. Sed. Res., 68, 684-699.

Jiang, G., Christie-Blick, N., Kaufman, A.J., Banerjee, D.M. and Rai, V. (2002) Sequence stratigraphy of the terminal Proterozoic Krol Group and Infra Krol Formation, Lesser Himalaya, India. J. Sed. Res., 72, 524-542.

Kahle, C.F. (1988) Surface and subsurface paleokarst, Silurian Lockport, and Peebles Dolomites, Western Ohio. In: Paleokarst (Eds J.P. James and P.W. Choquette), pp. 229235. Springer-Verlag, New York.

Kaufman, A.J., Knoll, A.H. and Narbonne, G.M. (1997) Isotopes, ice ages, and terminal Proterozoic earth history. Proc. Natl. Acad. Sci. USA, 94, 6600-6605.

Kennedy, M.J., Runnegar, B., Prave, A.R., Hoffmann, K.H. and Arthur, M.A. (1998) Two or four Neoproterozoic glaciations? Geology, 26, 1059-1063.

Kerans, C. and Donaldson, J.A. (1988) Proterozoic paleokarst profile, Dismas Lakes Group, N.W.T., Canada. In: Paleokarst (Eds J.P. James and P.W. Choquette), pp. 167-182. SpringerVerlag, New York.

Klein, G.deV. (1971) A sedimentary model for determining paleotidal range. Geol. Soc. Am. Bull., 82, 2585-2592.

Kumar, G., Bhatt, D.K. and Raina, B.K. (1987) Skeletal microfauna of Meishucunian and Qiongzhusian (Precambrian-Cambrian boundary) age from the Ganga Valley, Lesser Himalaya, India. Geol. Mag., 124, 167-171.

Kumar, R. and Brookfield, M.E. (1987) Sedimentary environments of the Simla Group (upper Precambrian), Lesser Himalaya, and their paleotectonic significance. Sed. Geol., 52, 27-43.

MacDonald, A.C., Falt, L.M. and Hektoen, A.L. (1998) Stochastic modeling of incised valley geometries. AAPG Bull., 82, 1156-1172.

Mathur, V.K. and Shanker, R. (1989) First record of Ediacaran fossils from the Krol Formation, Nainital syncline. J. Geol. Soc. India, 34, 245-254.

Mathur, V.K. and Shanker, R. (1990) Ediacaran medusoids from Cambrian Tal Formation, Himachal Lesser Himalaya and the Krol Formation, Naini Tal syncline. J. Geol. Soc. India, 36, 74-78.

Montañez, I.P. and Osleger, D.A. (1993) Parasequence stacking patterns, third-order accommodation events, and sequence stratigraphy of Middle to Upper Cambrian platform carbonates, Bonanza King Formation, southern Great basin. In: Carbonate Sequence Stratigraphy - Recent Developments and Applications (Eds R.B. Loucks and J.F. Sarg), AAPG Mem.,57, 305-325.

Montañez, I.P. and Read, J.F. (1992) Eustastic sea-level control on early dolomitization of peritidal carbonates: evidence from the Early Ordovician, Upper Knox Group, Appalachians. Geol. Soc. Am. Bull., 104, 872-886.

Mustard, P.S. and Donaldson, J.A. (1990) Paleokarst breccias, calcretes, silcretes and fault breccias at the base of Upper Proterozoic 'Windermere' strata, northern Canadian Cordillera. J. Sed. Petrol., 60, 525-539.

Najman, Y. and Garzanti, E. (2000) Reconstructing early Himalaya tectonic evolution and paleogeography from Tertiary foreland basin sedimentary rocks, northern India. Geol. Soc. Am. Bull., 112, 435-449.
Nielsen, P., Swennen, R., Muchez, P.H. and Keppens, E. (1998) Origin of Dinantian zebra dolomites south of the Brabant-Wales Massif, Belgium. Sedimentology, 45, 727743.

Nio, S.D. and Yang Chang-Shu (1991) Diagnostic attributes of clastic tidal deposits: a review. In: Clastic Tidal Sedimentology (Eds D.G. Smith, G.E. Reinson, B.A. Zaitlin and R.A. Rahmani), Can. Soc. Petrol. Geol. Mem., 16, 3-28.

Osleger, D.A. and Montañez, I.P. (1996) Cross-platform architecture of a sequence boundary in mixed siliciclasticcarbonate lithofacies, Middle Cambrian, southern Great Basin, USA. Sedimentology, 43, 197-217.

Osleger, D.A. and Read, J.F. (1991) Relation of eustasy to stacking patterns of meter scale carbonate cycles, Late Cambrian, USA. J. Sed. Petrol., 61, 1225-1252.

Pant, C.C. and Shukla, U.K. (1999) Nagthat Formation: An example of a progradational, tide-dominated Proterozoic succession in Kumaun Lesser Himalaya, India. J. SE Asian Earth Sci., 7,353-368.

Pelechaty, S.M. and Grotzinger, J.P. (1988) Stromatolites bioherms of a 1.9 Ga foreland basin carbonate ramp, Beechey Formation, Kilohigok Basin, Northwest Territories. In: Reefs - Canada and Adjacent Areas (Eds H. Geldsetzer, N.P. James and G. Tebbut), Can. Soc. Petrol. Geol. Mem., 13, 93-104.

Pelechaty, S.M. and James, N.P. (1991) Dolomitized Middle Proterozoic calcretes, Bathurst Inlet, northwest Territories, Canada. J. Sed. Petrol., 61, 988-1001.

Pelechaty, S.M., Grotzinger, J.P., Kashirtsev, V.A. and Zhernovsky, V.P. (1996) Chemostratigraphic and sequence stratigraphic constraints on Vendian-Cambrian basin dynamics, northeast Siberian craton. J. Geol., 104, 543-564.

Perlmutter, M.A., Radovich, B.J., Matthews, M.D. and Kendall, C.G.St. C. (1998) The impact of high-frequency sedimentation cycles on stratigraphic interpretation. In: Sequence Stratigraphy - Concepts and Applications (Eds F.M. Gradstein, K.O. Sandvik and N.J. Milton), pp. 141-170. Elsevier, Amsterdam.

Plint, A.G., Hart, B.S. and Donaldson, W.S. (1993) Lithosphere flexture as a control on stratal geometry and facies distribution in Upper Cretaceous rocks of the Alberta foreland basin. Basin Res., 5, 69-77.

Powers, P.M., Lillie, R.J. and Yeats, R.S. (1998) Structure and shortening of the Kangra and Dehra Dun re-entrants, SubHimalaya, India. Geol. Soc. Am. Bull., 110, 1010-1027.

Pratt, B.R. and James, N.P. (1986) The St George Group (Lower Ordovician) of western Newfoundland: tidal flat island model for carbonate sedimentation in shallow epeiric seas. Sedimentology, 33, 313-343.

Pratt, B.R., James, N.P. and Cowan, C.A. (1992) Peritidal carbonates. In: Facies Models: Response to Sea Level Changes (Eds R.G. Walker and N.P. James), Geol. Assoc. Can., 303-322.

Read, J.F. (1985) Carbonate platform facies models. $A A P G$ Bull., 69, 1-21.

Rupke, J. (1974) Stratigraphic and structural evolution of the Kumaon Lesser Himalaya. Sed. Geol., 11, 81-265.

Sami, T.T. and James, N.P. (1993) Evolution of an early Proterozoic foreland basin carbonate platform, lower Pethei Group, Great Slave Lake, north-west Canada. Sedimentology, 40, 403-430.

Sami, T.T. and James, N.P. (1994) Peritidal carbonate platform growth and cyclicity in an early Proterozoic foreland basin, Upper Pethei Group, northwest Canada. J. Sed. Res., B64, 111-131. 
Saxena, M.N. (1981) Chronology of tectonic events of the Himalaya. In: Metamorphic Tectonites of the Himalaya (Ed. P.S. Saklani), pp. 303-348. Today and Tomorrow's Publishers, New Delhi.

Schieber, J. (1994) Evidence for high-energy events and shallow-water deposition in the Chattanooga Shale, Devonian, central Tennessee, USA. Sed. Geol., 93, 193-208.

Schieber, J. (1999) Distribution and deposition of mudstone facies in the upper Devonian Sonyea Group of New York. J. Sed. Res., 69, 909-925.

Schlager, W. (1981) The paradox of drowned reefs and carbonate platforms. Geol. Soc. Am. Bull., 92, 197-211.

Shanker, R. and Mathur, V.K. (1992) Precambrian-Cambrian sequence in Krol Belt and additional Ediacaran fossils. Geophytology, 22, 27-39.

Shanker, R., Kumar, G. and Saxena, S.P. (1989) Stratigraphy and sedimentation in Himalaya, a reappraisal. Geol. Surv. India Spec. Publ., 26, 1-60.

Shanker, R., Kumar, G., Mathur, V.K. and Johsi, A. (1993) Stratigraphy of Blaini, Infra Krol and Tal succession, Krol Belt, Lesser Himalaya. Indian J. Petrol. Geol., 2, 99-136.

Shanker, R., Mathur, V.K., Kumar, G. and Srivastava, M.C. (1997) Additional Ediacaran biota from the Krol Group, Lesser Himalaya, India and their significance. Geosci. J., 18, 79-91.

Shinn, E.A. (1986) Modern carbonate tidal flats: their diagnostic features. In: Carbonate Depositional Environments. Part 3. Tidal Flats (Eds L.A. Hardie and E.A. Shinn), Colorado School Mines Q., 81, 7-35.

Singh, I.B. (1980a) Sedimentological evolution of the Krol Belt sediments. Himalayan Geol., 8, 657-683.

Singh, I.B. (1980b) Precambrian sedimentary sequences of India: their peculiarities and comparison with modern sediments. Precambrian Res., 12, 411-436.

Singh, I.B. and Rai, V. (1980) Some observations on the depositional environment of the Krol Formation in Nainital area. Himalayan Geol., 8, 633-656.

Singh, I.B. and Rai, V. (1983) Fauna and biogenic structures in Krol-Tal succession (Vendian-Early Cambrian), Lesser Himalaya and a biostratigraphic and palaeontological significance. J. Paleontol. Soc. India, 28, 67-90.

Singh, I.B., Rai, V. and Bhargava, A.K. (1980) Some observations on the sedimentology of the Krol succession of Mussoorie area, Uttar Pradesh. J. Geol. Soc. India, 21, 232238.

Singh, S., Barley, M.E., Brown, S.J., Jain, A.K. and Manickavasagam, R.M. (2002) SHRIMP U-Pb in zircon geochronology of the Chor granitoid: evidence for Neoproterozoic magmatism in the Lesser Himalayan granite belt of NW India. Precambrian Res., 118, 285-292.
Sohl, L.E., Christie-Blick, N. and Kent, D.V. (1999) Paleomagnetic polarity reversals in Marinoan ( $\sim 600 \mathrm{Ma})$ glacial deposits of Australia: implications for the duration of lowlatitude glaciation in Neoproterozoic time. Geol. Soc. Am. Bull., 111, 1120-1139.

Southgate, P.N. (1989) Relationships between cyclicity and stromatolite form in the Late Proterozoic Bitter Springs Formation, Australia. Sedimentology, 36, 323-339.

Sweet, K. and Knoll, A.H. (1989) Marine pisolites from Upper Proterozoic carbonates of East Greenland and Spitsbergen. Sedimentology, 36, 75-93.

Tangri, A.K. and Singh, I.B. (1982) Palaeoenvironment of Blaini Formation, Lesser Himalaya. J. Paleontol. Soc. India, 27, 35-48.

Tiwari, M. and Knoll, A.H. (1994) Large acanthomorphic acritarchs from the Infrakrol Formation of the Lesser Himalaya and their stratigraphic significance. J. Himalayan Geol., 5, 193-201.

Tompkins, L.A., Murray, J.R., Groves, D.I. and Roche, M.T. (1994) Evaporites: in situ sulfur source for rhythmically banded ore in the Cadjebut Mississippi Valley-type Zn-Pb deposits, Western Australia. Econ. Geol., 89, 467-492.

Torsvik, T.H., Carter, L.M., Ashwal, L.D., Bhushan, S.K., Pandit, M.K. and Jamtveit, B. (2001) Rodinia refined or obscured: palaeomagnetism of the Malani igneous suite (NW India). Precambrian Res., 108, 319-333.

Valdiya, K.S. (1970) Simla Slates: the Precambrian Flysch of the Lesser Himalaya, its turbidites, sedimentary structures and paleocurrents. Geol. Soc. Am. Bull., 81, 451-468.

Virdi, N.S. (1991) Sedimentation and tectonics of the Krol belt - control of basement structures on the basin configuration. J. Himalayan Geol., 2, 141-149.

Wallace, M.W., Both, R.A., Ruano, S.M., Hach-Ali, P.F. and Lees, T. (1994) Zebra textures from carbonate-hosted sulfide deposits: sheet cavity networks produced by fracture and solution enlargement. Econ. Geol., 89, 1183-1191.

Wright, V.P. (1982) The recognition and interpretation of paleokarsts: two examples from the Lower Carboniferous of south Wales. J. Sed. Petrol., 52, 83-94.

Wright, V.P. (1994) Paleosols in shallow marine carbonate sequences. Earth-Sci. Rev., 35, 367-395.

Zaitlin, B.A., Dalrymple, R.W. and Boyd, R. (1994) The stratigraphic organization of incised-valley systems associated with relative sea-level change. In: Incised Valley Systems: Origin and Sedimentary Sequences (Eds R. Dalrymple, R. Boyd and B. Zaitlin), SEPM Spec. Publ., 51, 45-60.

Manuscript received 25 October 2002; revision accepted 20 May 2003. 